Original paper

\title{
Geochemical and structural constraints on the magmatic history of the Chandman Massif of the eastern Mongolian Altay Range, SW Mongolia
}

\author{
Rita C. ECONOMOS ${ }^{1, *}$, Pavel HANŽL2, Kristýna HRDLIČKOVÁ2, David BURIÁNEK², Lkhagva-Ochir \\ SAID $^{3}$, Axel GERDES ${ }^{4}$, Scott R. PATERSON ${ }^{1}$ \\ ${ }^{1}$ Department of Earth Sciences, University of Southern California, 3651 Trousdale Parkway ZHS117, Los Angeles, CA 90089-0740, \\ USA; economos@usc.edu \\ ${ }^{2}$ Czech Geological Survey, Leitnerova 22, 65869 Brno, Czech Republic \\ ${ }^{3}$ School of Geology and Petroleum Engineering, Mongolian University of Science and Technology, Box 520, P.O. 46, Ulaanbaatar, \\ Mongolia 210646 \\ ${ }^{4}$ Institut für Geowissenschaften, Goethe Universität, Altenhöferallee 1; 60438 Frankfurt am Main; Germany \\ * Corresponding author
}

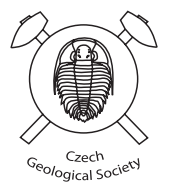

In the Mongolian Altay range, immediately south of the Bogd fault zone, the Chandman Massif intruded the Chandman Khayrkhan Crystalline Complex to the NE. This complex consists of migmatized biotite gneisses, orthogneisses and amphibolites. To the south, the Massif cuts the chlorite schists and quartzites of the Tugrug Formation. The Massif mainly consists of diorites to granites with rare gabbro bodies interspersed with metamorphic host rock screens, generally of amphibolite with calc-silicate lenses. Granitoids are further categorized based on petrography and whole-rock geochemical data into peraluminous and metaluminous groups. Granites comprise the peraluminous group, and possess high (71-77 wt. \%) silica contents with abundant modal K-feldspar. Metaluminous granitoids span a wide range in silica contents, from diorite to granite. Also their feldspars are compositionally variable. Both these granitoid units are of volcanic-arc character and display a calc-alkaline geochemical trend. Granodiorites of the metaluminous group contain widespread planar rhythmic schlieren layering. Metaluminous units slightly predate the intrusion of peraluminous granites, but the two suites are occasionally co-magmatic. The Al-in-hornblende barometric analysis combined with plagioclase thermometry reveals a depth of emplacement of $11.5-13.7 \mathrm{~km}$ and magma temperatures of $725-775^{\circ} \mathrm{C}$. Chandman Khayrkhan metamorphic foliations strike NNW. Magmatic fabrics in the Chandman Massif roughly E-W and subparallel E-W solid-state foliations overprint magmatic foliations. All foliations are moderately to steeply dipping. Fabric analysis shows a discordance of structures to the north and south of a fault that cross-cuts the field area. This fault is interpreted to be related to motion on the Bogd Fault. Thus, this area experienced 1) amphibolite-facies metamorphism of the Chandman Khayrkhan Crystalline Complex, 2) exhumation to higher crustal levels, 3) juxtaposition against the greenschist-facies Tugrug Formation, 4) intrusion of the Chandman Massif under tectonic strains that continued through the solidification of plutons, and 5) late block-style rotation related to motion on recent faults. These age and geological constraints identify the Chandman Massif as an intrusion of substantially younger age than the "Caledonian" association into which it was previously placed. It is thus far the only arc-type intrusion in the earliest "Hercynian" age range identified in the Gobi-Altay Terrane. Its metamorphic and magmatic history of migmatization followed by intrusion of metaluminous and peraluminous plutons are similar to those of rocks to the west, in the Tseel Terrane, and may represent its easternmost counterpart. The exact juxtaposition mechanism for metamorphic units of different grade and the formation of schlieren layering in the Chandman Massif granodiorites remain enigmatic.

Keywords: Mongolian Altay, Al-in-hornblende barometry, Gobi-Altay Terrane, magmatism, arcs, granite, Chandman Massif

Received: 15 April 2008; accepted 19 December 2008; handling editor: J. Žák

The online version of this article (doi: 10.3190/jgeosci.034) contains supplementary electronic material.

\section{Introduction}

The Mongolian Altay is a young intraplate transpressional orogen developed during the Late Cenozoic uplift of central Mongolia (Cunningham 2005). Although it is morphologically young, an important boundary between the northern and southern geological domains of Mongolia occurs in this mountain range. The northern domain is usually classified as belonging to the Caledonian orogen and the southern domain to the Hercynian orogen (Marinov et al. 1973). Although the terms of Caledonian or Hercynian are inappropriate for the complicated geological collage of Central Asian Orogenic Belt, the basic two-fold subdivision for Mongolia into northern and southern domains is still applicable (Badarch et al. 2002). The so-called Main Mongolian Lineament sepa- 
rates dominantly Proterozoic and Lower Paleozoic rocks to the north from Lower to Upper Paleozoic rocks in the south (Fig. 1, inset).

The area we discuss below lies immediately to the south of the recently active Cenozoic Bogd fault zone (Molnar and Tapponnier 1975). The area is situated in the surroundings of the Chandman town (Fig. 1) (Govi Altay Aymag, SW Mongolia), approximately 750 km SW of Ulaanbaatar at the junction of south-eastern Mongolian Altay with western Gobi Altay.

This area has been identified by several workers as the transition zone between the "Caledonian" and "Hercynian" provinces (Dergunov 2001; Badarch et al. 2002, references therein). The transition between these phases of magmatism is proposed to represent the collision and consolidation of Caledonian and Hercynian magmatic arcs and the reinitiation of subduction beneath the amalgamated continental margin (e.g. Kovalenko et al. 2004, Table 1). The study area lies in the heart of this transitional zone, and has thus drawn recent attention and attracted detailed studies (Kovalenko et al. 2004; Kozakov et al. 2007; Kröner et al. 2007).

In this paper, we will present new mapping, structural and petrographic data to describe temporal and geochemical relationships between magmatic rocks of the Chandman Massif and its metamorphic host rocks. Magmatic rocks of the Chandman Massif are further characterized into metaluminous and peraluminous units based on field evidence, geochemistry, and petrography. The timing and conditions of intrusion are constrained by previous geochronology (Hrdličková et al. 2008) and new geothermobarometry. These data are combined to create a model of the metamorphic and intrusive history of the area.

\section{Geological setting}

\subsection{General geological and tectonic setting}

Mongolia consists of a number of tectonic zones that form the part of the extensive Central Asian Orogenic Belt (CAOB) (Mossakovsky et al. 1994) known also as the Altaid Tectonic Collage (Sengör et al. 1993). This belt occurs between the Siberian Craton in the north, the Tarim Craton in the southwest and the Sino-Korean Craton in the south. It is characterized by a collage of various terranes of different origin (Sengör et al. 1993; Windley et al. 2002; Jahn et al. 2004) and evolved in the time span of 1000-250 Ma (Windley et al. 2007). The CAOB is characterized by an abundance of Paleozoic and Mesozoic granitic intrusions as well as basaltic to rhyolitic volcanics (e.g. Jahn et al. 2000), and is known as an important site of Late Precambrian to Phanerozoic juvenile crustal growth (Sengör et al. 1993; Hu et al.

$98^{\circ} 10^{\prime} 0^{\prime \prime} \mathrm{E}$

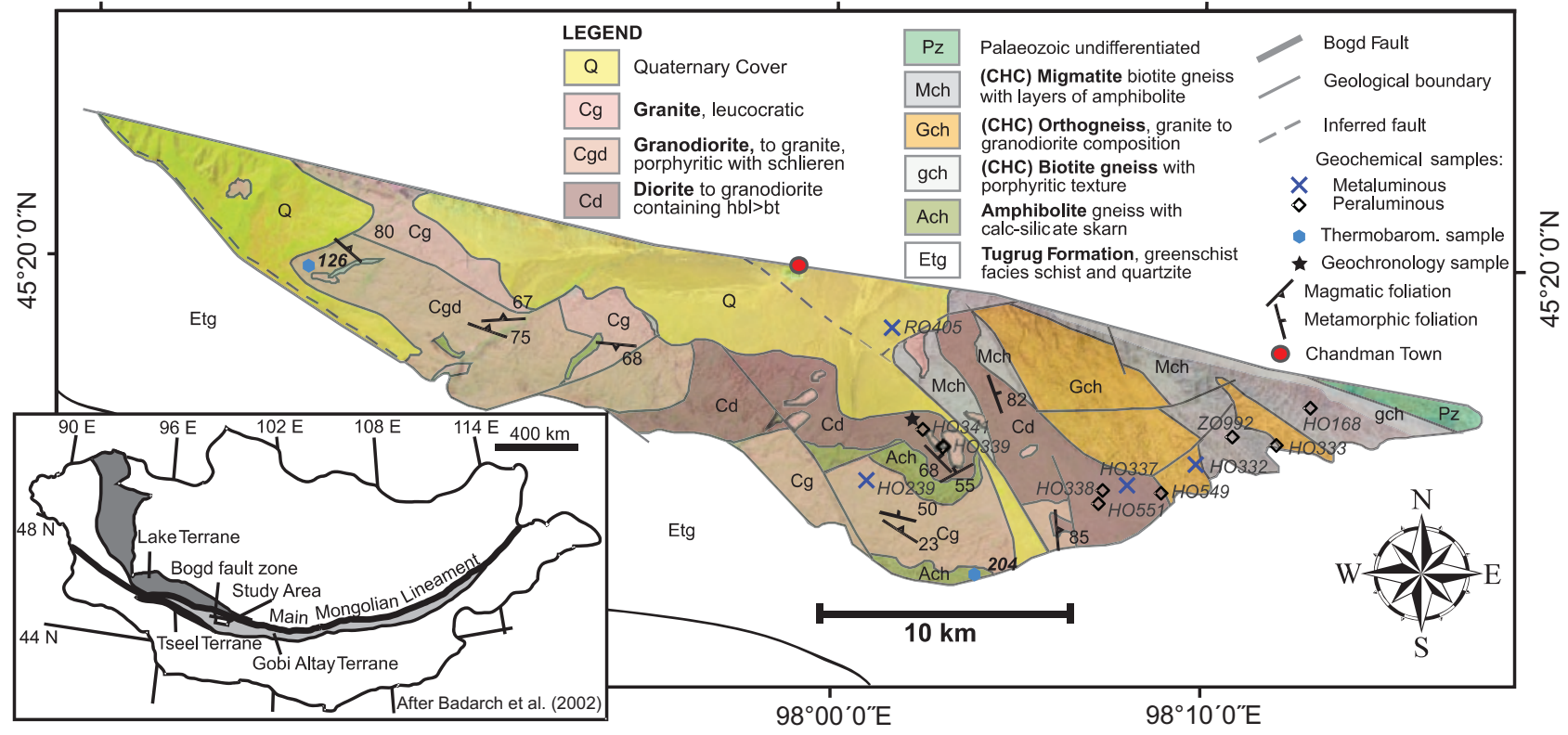

Fig. 1 Geologic map of the Chandman Massif and adjacent metamorphic host rocks. CHC - Chandman Khayrkhan Crystalline Complex. Locations of samples for geochemistry and thermobarometry detailed. Foliation data are selected as representative averages for magmatic and metamorphic foliations. Inset map is modified after Badarch et al. (2002). 
2000; Jahn et al. 2000; Jahn et al. 2004). Granitoids have a wide range of compositions and show a temporal evolution from calc-alkaline and alkaline to peralkaline series. The emplacement of most granitic plutons falls between 500 and 120 Ma (Jahn et al. 2000).

In the terrane division of Mongolia by Badarch et al. (2002), the studied area is situated within the Gobi Altay Terrane at its northern margin, near the boundary with the Lake Terrane. The boundary between these two units coincides here with the Chandman strand of the Bogd fault zone (Baljinnyam et al. 1993).

The Gobi-Altay Terrane most likely represents the southwestern continental margin of the Siberian Plate. According to Badarch et al. (2002), it forms a long narrow belt rimming the northern margin of the southern domain of Mongolia. It is composed of Cambrian (?) marine sediments and volcaniclastic rocks metamorphosed under greenschist-facies conditions accompanied by Paleozoic sediments, volcanic and volcaniclastic rocks of a forearc/ backarc character. The sequence was intruded mainly by Carboniferous to Permian granite plutons.

The Lake Terrane is composed of slightly metamorphosed volcanosedimentary sequences of Neoproterozoic to Lower Paleozoic ages, which alternate with highly metamorphosed rocks in the Zamtyn Nuruu and Alag Khadny Crystalline Complexes and with relics of oceanic crust (Hanžl and Aichler eds. 2007). The Permian volcanic and volcaniclastic sequences covering the Lower Paleozoic units are tectonically incorporated into the structure of the Lake Terrane along its southern boundary.

The study area occurs spatially in the "Caledonian" province (generally of Cambrian to Ordovician age) of Kovalenko et al. (2004) where Nd model ages of $~ 900$ $\mathrm{Ma}$ of felsic igneous rocks indicate the incorporation of older crustal material in their generation. Kozakov et al. (2007) also referred to this area as falling into the Caledonides of the north Asian continental margin, while the adjacent Tseel Terrane to the west (also of Badarch et al. 2002), has been characterized as the northernmost representation of "Hercynian" (generally of Ordovician to Early Carboniferous age) tectonic and magmatic activity. Kröner et al. (2007) similarly described the study area as being built by Ordovician metavolcanics and plutonics. According to map patterns (Kröner et al. 2007, fig. 17), the area represents a sliver of older material bounded to the south by younger Devonian granites, metavolcanics and metasedimentary sequences, and to the north (across the Bogd fault zone) by Permian volcanics and granites. These interpretations, however, are inconsistent with geochronological findings and the geological character of the Chandman Khayrkhan Crystalline Complex, as described below, in Hrdličková et al. (2008) and in geological maps (Hanžl and Aichler 2007).

\subsection{Geology of the Chandman Massif and adjacent metamorphic units}

The Chandman Massif is located in the eastern part of the Mongolian Altay Mountains. It is exposed in an E-W elongated, oval-shaped body in the region of the Chandman Khayrkhan Mountain near the town of Chandman (Fig. 1). Plutons of the Chandman Massif span a wide compositional range, from diorite to granite. A variety of preserved magmatic structures are overprinted by mild to moderate solid-state deformation. The Massif intruded migmatites of the Chandman Khayrkhan Crystalline Complex in the northeast. The contact between metamorphic rocks and the Chandman Massif is disrupted by NW-SE trending faults on the SW slopes of the Chandman Khayrkhan Mountain. The boundary with the Paleozoic volcanosedimentary sequence in the NW is overprinted by mylonite zones associated with the Chandman rupture of the Bogd Fault. The southern, intrusive contact with the moderately metamorphosed volcanosediments of the Tugrug Formation of supposed Cambrian age (Rauzer et al. 1987) is commonly obscured by faults. The eastern termination of the Massif is covered by Quaternary alluvial fans. The Tugrug Formation and the Chandman Khayrkhan Crystalline Complex are never observed in contact, always being separated by granitoids of the Chandman Massif.

The Chandman Khayrkhan Crystalline Complex consists of migmatites, orthogneisses, gneisses and amphibolites with lenses of skarn-like rocks. Reconstruction of the metamorphic evolution of this unit is also complicated due to overprinting by HT-LP metamorphism related to the intrusion of the Chandman Massif. The main mineral assemblages indicate amphibolite-facies metamorphism. The mentioned rocks are affected by extensive migmatitization which was likely dominantly related to a pre-intrusive metamorphic event (based on data presented below). Lit-par-lit intrusion by Chandman Massif granites suggests that partial melting caused by high temperatures and fluid flow during granite emplacement also contributed to local migmatization. Discrimination between the magmatic products of migmatization of the Chandman Khayrkhan Crystalline Complex and the peraluminous granites of the Chandman Massif was made on subtle field relationships, which are discussed at length below. For example, structural relationships of $\mathrm{cm}$ thick pegmatite dikes of the mineral composition identical to the migmatite leucosomes indicate that these dikes were mainly related to the emplacement of the Chandman Massif.

The Tugrug Formation is exposed along the southern and western contact of the Massif. The formation is composed of siliceous, green-gray chlorite-sericite schists with intercalations of light gray quartzites. Layers of 
metabasalts and tuffaceous sandstones are minor. Units with greenschist-facies assemblages grade into biotite gneiss and amphibolite towards the Chandman Massif. Bedding is not preserved here, and the dominant structure is the NW-SE oriented crenulated foliation with a prevailing dip (moderate to steep) toward the SW. The sequence is folded by close to tight overturned folds with amplitudes of up to $1 \mathrm{~m}$ and a NW-SE orientation of fold axes.

Intrusive boundaries between the Tugrug Formation and Chandman Massif are frequently disrupted by faults. Equivalents of Tugrug Formation are preserved as remnants of metamorphic wall rocks of the Chandman Massif. Rauzer et al. (1987) interpreted crystalline rocks of the Chandman Khayrkhan Mountain situated towards the north as a part of the Tugrug Formation. However, the lithology and character of metamorphism enable us to separate these rocks from the Tugrug Formation proper.

The Chandman Massif includes plutonic suites of both metaluminous and peraluminous character. Metaluminous plutons span a wide compositional range from diorite to granite. Dioritic units were grouped in the field based on proportions of both feldspars, the occurrence of hornblende, the presence of microgranitoid enclaves, and a characteristic rhythmic planar schlieren layering. Some granites of the Chandman Massif were grouped with these units based on their spatial association and common gradational contacts with granodiorites. Porphyritic biotite granodiorite forms the southern part of the Massif, whereas the biotite to biotite-amphibole granodiorite and tonalite units are situated in the northern part (Fig. 1). The boundary is commonly marked by a discontinuous belt of amphibolites and gneisses in roof pendants of the Massif.

Peraluminous granites were identified based on the presence of primary muscovite, color index, and their common occurrence in the vicinity of the Chandman Khayrkhan Crystalline Complex. Compositions of these rocks represent a narrow range from biotite to leucocratic biotite granite and they have a monotonous macroscopic appearance. These units were intruded into granodiorites and diorites in the northern part of the Chandman Massif and in some cases display mutually intrusive relationships with these rocks.

All plutonic units in the Chandman Massif display magmatic fabrics, defined by the statistical alignment of minerals with high axial ratios. These fabrics are presumed to represent strain in plutons during the final stages of crystallization (Paterson et al. 1998). In more mafic units, internal heterogeneities such as schlieren layering and elongate mafic enclaves are aligned parallel to this fabric. Granitoids also display a solid-state foliation in many localities, defined in the field by stretched quartz crystals and in thin section by the presence of subsolidus microstructures. The intensity of this deformation increases towards the northeast where granitic rocks grade into orthogneisses. The contact between orthogneisses of the Chandman Khayrkhan Crystalline Complex and the Chandman Massif is gradational.

\section{Petrography}

\subsection{Petrography of metamorphic rocks}

\subsubsection{Tugrug Formation}

The Tugrug Formation (Etg - index used in Fig. 1) is dominated by siliceous, chlorite-sericite schists, with layers of greenschists and quartzite. The composition of rocks varies from sericite phyllite to greenschist. Chlorite schists are fine-grained, banded with lepidoblastic microstructure and a mineral association of quartz + albite + sericite + chlorite \pm epidote \pm biotite \pm carbonate. Opaque minerals and tourmaline appear as accessories. Metabasalts, tuffaceous green-gray, slightly metamorphosed sandstones, greenschists, and quartzite form elongate lenses in the schists, typically with gradational contacts. The metabasalts are fine-grained, massive rocks, locally with relics of tabular phenocrysts of altered feldspars and chloritized amphibole. The groundmass consists of actinolite, chlorite, epidote and opaque minerals. Titanite is accessory. Fine-grained, banded amphibolite with calc-silicate lenses form a narrow, morphologically prominent range exposed together with gneisses near the contact with the Chandman Massif. Amphibolites have poikiloblastic texture and are composed of amphibole, plagioclase, epidote and rare quartz. Titanite is accessory. The amphibolite contains lenses of calc-silicate rocks composed of epidote, quartz and plagioclase.

Fine-grained, laminated quartzites are exposed in thin layers, forming resistant ridges in the chlorite-sericite schist. They are fine- to very fine-grained rocks composed of elongated quartz grains and sericite oriented in the foliation. The trend of the layers is parallel with the foliation. Biotite to chlorite-biotite schists are exposed together with amphibolites in two belts. They also are exposed in the marginal part of the unit near the contact with the Chandman Massif. Main phases are plagioclase, quartz, biotite, sometimes muscovite and locally cordierite.

\subsubsection{Chandman Crystalline Complex}

Orthogneiss (Gch) forms bodies in migmatites on the SE slopes of the Chandman Khayrkhan Mountain. It is a medium-grained rock of granodiorite to granite composition 
with locally porphyroblastic texture. It is composed of K-feldspar, plagioclase, interstitial quartz, minor biotite and muscovite. Interstitial quartz is often recrystallized to very fine-grained mosaics, and K-feldspars are partially recrystallized.

Fine-grained metagranite, locally garnet-bearing, alternated with meta-aplite, metapegmatite, and gneiss forms discontinuous dikes and small lenticular bodies in migmatites and granites on the SE slopes of the Chandman Khayrkhan Mountain. The rocks have a granular texture that gives them a massive appearance. This fine-grained character is accentuated by homogeneous distribution of the major mineral components (K-feldspar, plagioclase, quartz and biotite). Quartz forms grains with sutured contacts and exhibit undulatory extinction. Accessory minerals are apatite, zircon and occasionally garnet.

Red porphyritic metagranites are fine- to mediumgrained equigranular rocks with plagioclase and biotite phenocrysts. The groundmass consists of plagioclase (30-40 \%), K-feldspar (20-30 \%), quartz (15-20\%) and biotite (10-15\%). Accessory minerals include muscovite, epidote, apatite and zircon.

Metagranodiorite to metadiorite are the prevailing rocks in the central part of the Chandman Khayrkhan Crystalline Complex. Microscopic examination reveals that the protolith was similar to granodiorite and diorite of the Chandman Massif. Granular texture is typical, occasionally with a distinct subsolidus fabric defined by thin flakes of biotite and alternating domains of recrystallized feldspar and deformed quartz. Average grain size is up to $1 \mathrm{~mm}$, often with plagioclase or microcline sericitized. Quartz and perthitic microcline form subhedral or elongate grains, mostly or partially recrystallized. Accessory minerals are apatite, zircon, epidote, magnetite and titanite.

Biotite-amphibolite gneiss to amphibolite to hornblende gneiss with skarn and metagabbro lenses (Ach) form layers surrounded by migmatites or metaigneous rocks. The largest bodies are exposed in migmatites on the eastern slope of the Chandman Khayrkhan Mountain. These medium- to fine-grained, commonly banded rocks have varied amphibole content (30-70 modal \%). Amphibolites also usually contain anorthitic plagioclase $\left(\mathrm{Ab}_{7-11}\right)$, quartz, and secondary chlorite. Minor biotite, ore minerals and titanite are locally present. Amphibolites are often migmatized or interlayered with migmatites. The metagabbro is composed of prevailing amphibole (more than $60 \%$ ), minor plagioclase, rare biotite and titanite, secondary epidote, calcite and sericite. The skarns consist mainly of garnet and pyroxene accompanied by interstitial quartz and plagioclase.

Biotite migmatite to pearl gneiss with anatectic textures, layers of amphibolite (Mch) surrounds metagranodiorite and metadiorite in the central part of the
Chandman Khayrkhan Crystalline Complex. The grain size is medium to coarse; biotite is common in both mafic and felsic lithologies. Plagioclase is often present as porphyroblasts. Layers of migmatized amphibolite are up to several dm thick and contain mainly hornblende and plagioclase, with minor quartz, biotite, epidote and titanite. The migmatites also contain layers of calc-silicate rock up to $30 \mathrm{~cm}$ thick. The calc-silicate rocks are composed mainly of biotite, plagioclase and quartz, and occasionally muscovite, sillimanite and garnet. Tourmaline occurs only locally in the migmatites, namely on the boundary between melanosome and leucosome.

Biotite gneiss and porphyroblastic gneiss (gch) осcurs in the belt in the northernmost part of the unit along the Ikh Bogd Fault. The gneiss is a medium-grained rock, composed of plagioclase, biotite, quartz and sometimes K-feldspar or muscovite, accessory zircon and apatite. Chloritization of biotite is common, and local melting occurs in rare localities in this unit.

Additional information on the described units, including mineralogical compositions determined by electron microprobe, is available in Hrdličková et al. (2008).

Metamorphic host-rock septa within the Chandman Massif include amphibolites, calc-silicate rocks, biotite schists, and rare quartzites. Very fine grained amphibolites are the most common and consist almost entirely of equigranular, stubby hornblende and plagioclase. Some amphibolites contain hornblende porphyroblasts up to $3 \mathrm{~mm}$ across with mottled textures and a very dark brown to dark green appearance. Calc-silicate rocks are dominated by calcite with extensive deformation twinning and grain size reduction. Biotite schists are rare and are mostly found near the contact with the Tugrug Formation. Blocks of this composition have undergone a small amount of partial melting, possibly associated with their engulfment in plutons. All host-rock blocks have undergone metamorphism and moderate temperature deformation before their integration into the massif, with quartz, where present, displaying grain size reduction and core and mantle structures.

\subsection{Petrography of plutonic rocks}

Diorite units are found throughout the Chandman Massif and are characterized by the profusion of long, lath-like plagioclase crystals (Fig. 2a), and large euhedral titanite crystals that can be observed in hand specimen. K-feldspars are rare to absent in these rocks. Mafic minerals include biotite and hornblende in varying proportions; hornblende crystals are subhedral and stubby. Prismatic epidote crystals are common and microstructural relationships confirm that it is a primary magmatic mineral (Fig. 2b). Apatite and magnetite are present as accessory phases. 

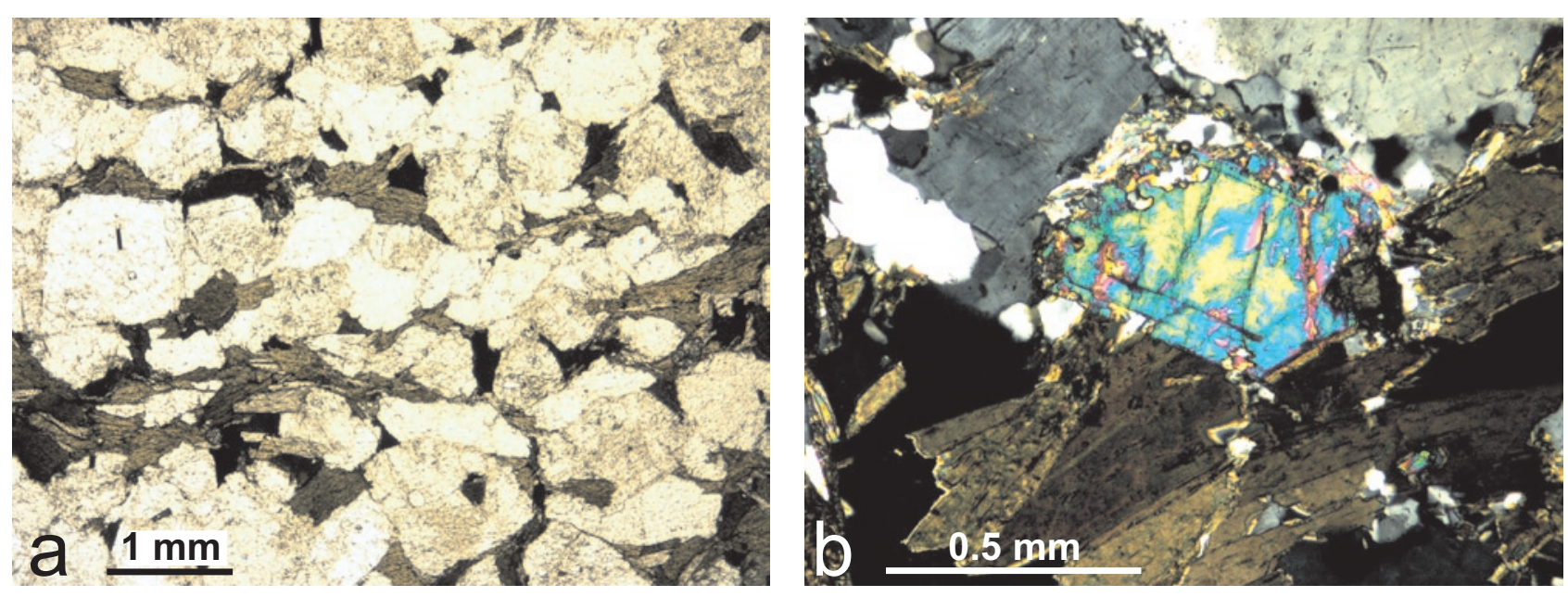

Fig. 2a - Photomicrographs of a biotite-rich schlieren layering characteristic of granodiorites in the Chandman Massif, and $\mathbf{b}$ - a subhedral epidote crystal situated between plagioclase and biotite demonstrating its magmatic origin.

Granodiorites with extensive planar schlieren layering are found in the southern portions of the massif. Petrographic observations support the interpretation that these rocks are petrologically related to the diorite units. Granodiorites share with diorites long subhedral plagioclase crystals, an abundance of euhedral gold-colored titanite, and accessory magnetite. The major petrologic difference between these two units is the presence of macroscopically perceptible K-feldspar grains. The schlieren distinctive to this unit appear as concentrations of aligned biotite books in thin section, but their matrix is otherwise of the granodioritic composition (Fig. 2a).

Granitic to leucogranitic units are peppered throughout the complex. They consist dominantly of K-feldspar and quartz crystals with plagioclase and biotite. K-feldspars sometimes form phenocrysts. While it is difficult to discern between metaluminous and peraluminous granites in the field, they can be subdivided geochemically and have some distinctive microstructural characteristics. Upon petrographic inspection, peraluminous granites are finer grained and display ubiquitous grain boundaries with a sutured appearance. All crystals are sub- to anhedral, and quartz is polycrystalline. Metaluminous granites tend to have larger grain sizes and more euhedral grains.

\section{Geochemistry and thermobarometry}

\subsection{Whole-rock geochemistry}

Samples from the main lithological types of at least 2-4 $\mathrm{kg}$ in mass were used for whole-rock geochemical analyses. Major and trace elements were determined at ACME Laboratories, Canada (Tab. 1a-b). Igneous rocks of the Chandman Massif range from diorite to granite (Fig. 3d).
Three types can be distinguished according to $\mathrm{SiO}_{2}$ content: granites (71-77 wt. \%), granodiorites with tonalites, (61-71 wt. \%) and diorites (55-59 wt. \%). Plutonic rocks are calc-alkaline (Fig. 3b), with potassium abundances corresponding to the high-K series for granites and medium-K series for tonalites to granodiorites (Fig. 3a). Analyzed plutonic samples can be separated into peraluminous and metaluminous suites based on A/CNK values and Eu anomaly magnitudes (Fig. 3c, 4a).

Peraluminous samples are acid $\left(\mathrm{SiO}_{2}=72-77\right.$ wt. \%) and display trace-element ratios $\mathrm{K} / \mathrm{Rb}$ of $145-265$ and $\mathrm{Rb} / \mathrm{Sr}$ of $1-11$. The total REE contents are low (49-166 $\mathrm{ppm})$. LREE are slightly to moderately fractionated $\left(\mathrm{La}_{\mathrm{N}} / \mathrm{Sm}_{\mathrm{N}}=2.1-5.5\right)$ and the HREE trends in chondritenormalized patterns are flat $\left(\mathrm{Gd}_{\mathrm{N}} / \mathrm{Yb}_{\mathrm{N}}=0.9-1.4\right)$. These rocks also have a pronounced negative Eu anomaly, demonstrated by Eu/Eu* ratios of 0.2-0.6 (Fig. 3f). In the NMORB-normalized spider diagram, there is depletion in $\mathrm{Ba}, \mathrm{Nb}, \mathrm{Sr}, \mathrm{P}$ and $\mathrm{Ti}$, slight depletion in $\mathrm{Zr}$ and enrichment in $\mathrm{Cs}, \mathrm{Rb}, \mathrm{Th}, \mathrm{K}, \mathrm{Pb}$ and MREE (Fig. 3e). Samples fall mainly within the Volcanic Arc Granite (VAG) field, and two samples into the Within Plate Granite (WPG) field of the classification by Pearce et al. (1984) (Fig. 4b-c). A shallow trend is also observed in the $\mathrm{CaO} / \mathrm{Na}_{2} \mathrm{O}$ vs. $\mathrm{Al}_{2} \mathrm{O}_{3} / \mathrm{TiO}_{2}$ binary plot, with most peraluminous samples having $\mathrm{CaO} / \mathrm{Na}_{2} \mathrm{O}<0.3$ (Fig. 4e). In addition half of peraluminous rocks sampled fall into the strongly peraluminous categorization, having A/CNK values of 1.1 to 1.3 (Fig. 3c) (Sylvester 1998). This suggests a pelitic source according to Sylvester (1998) and references therein.

Metaluminous rocks demonstrate a greater variety, including a wide range in $\mathrm{SiO}_{2}$ content, from 55 to 77 wt. \% (Fig. 3a). Samples show higher and much more variable $\mathrm{K} / \mathrm{Rb}$ ratios (142-519) than granite units. They are also 

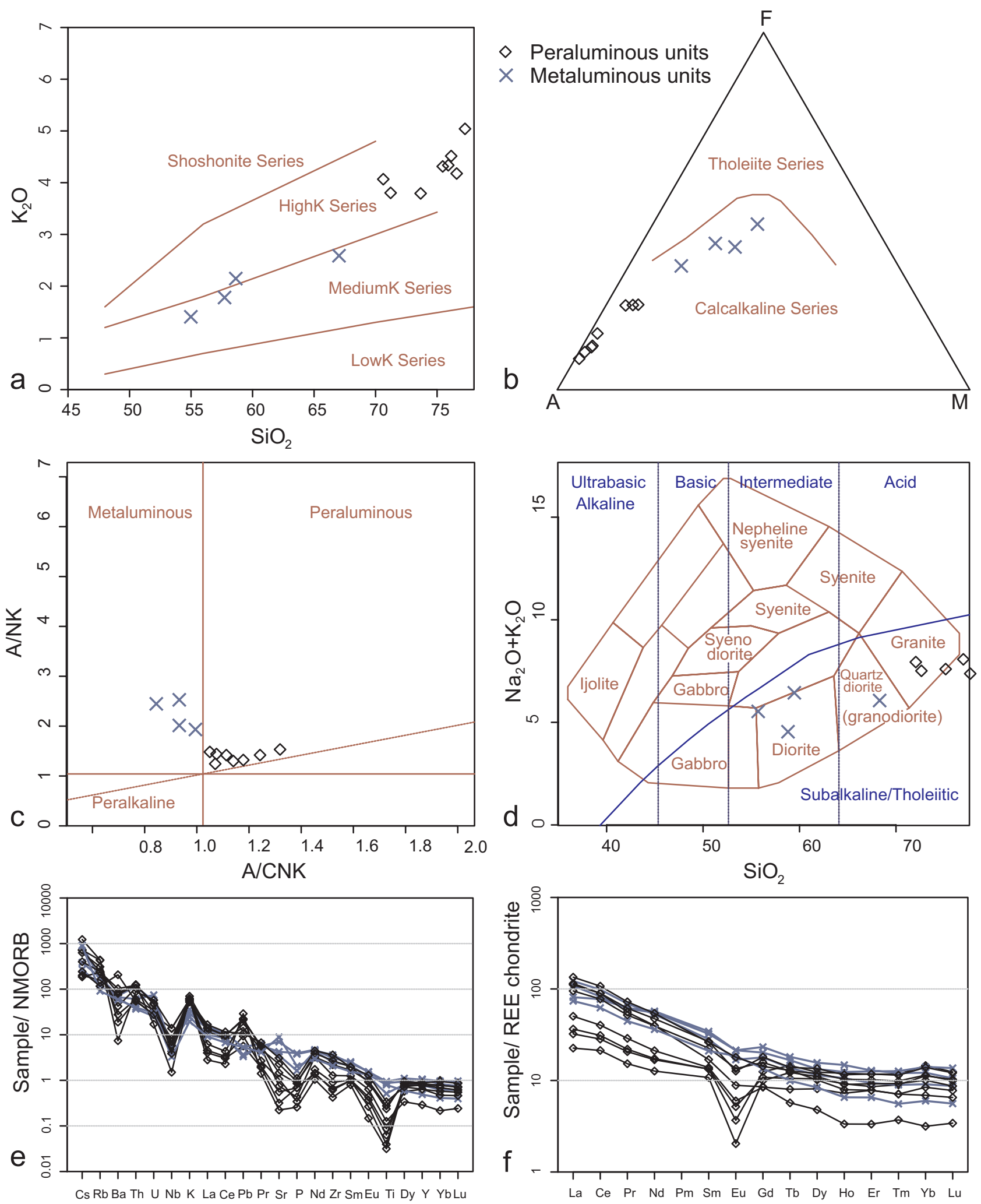

Fig. 3 Geochemistry of the Chandman Massif. a - $\mathrm{SiO}_{2}$ vs. $\mathrm{K}_{2} \mathrm{O}$ plot (Peccerillo and Taylor 1976), b - AFM diagram (Irvine and Baragar 1971), c $-\mathrm{A} / \mathrm{NK}$ vs. A/CNK plot (Shand 1943), $\mathbf{d}-\mathrm{Na}_{2} \mathrm{O}+\mathrm{K}_{2} \mathrm{O}$ vs. $\mathrm{SiO}_{2}$ (TAS) plot (Cox et al. 1979), e - Spider diagram normalized to NMORB (Sun and McDonough 1989), f - Rare earth element patterns normalized to chondrite (Boynton 1984). 
Tab. 1a Whole-rock major-element analyses (wt. \%) for igneous rocks of the Chandman Massif

\begin{tabular}{|c|c|c|c|c|c|c|c|c|c|c|c|c|}
\hline Sample & H0168 & H0239 & H0332 & H0333 & H0337 & H0338 & H0339 & H0341 & H0549 & H0551 & R0405 & Z0992 \\
\hline Sheet_no & \multicolumn{10}{|c|}{ L-47-101A } & L-47-89A & L-47-101A \\
\hline E_coord. $\left({ }^{\circ}\right)$ & 98.22329 & 98.02093 & 98.16809 & 98.19587 & 98.13047 & 98.11511 & 98.05684 & 98.03772 & 98.15180 & 98.11545 & 98.01052 & 98.17676 \\
\hline N_coord. $\left({ }^{\circ}\right)$ & 45.27573 & 45.25558 & 45.26511 & 45.26924 & 45.25467 & 45.25046 & 45.26844 & 45.27135 & 45.25055 & 45.24709 & 45.31053 & 45.27202 \\
\hline Rock & granite & granite & diorite & granite & diorite & granite & granite & diorite & granite & granite & diorite & granodiorite \\
\hline $\mathrm{SiO}_{2}$ & 75.48 & 58.63 & 57.72 & 76.12 & 67.06 & 76.58 & 73.67 & 71.19 & 77.29 & 75.94 & 54.99 & 70.64 \\
\hline $\mathrm{Al}_{2} \mathrm{O}_{3}$ & 14.00 & 17.44 & 15.43 & 13.43 & 15.20 & 12.99 & 13.31 & 14.11 & 11.49 & 13.22 & 19.48 & 14.16 \\
\hline $\mathrm{Fe}_{2} \mathrm{O}_{3}$ & 1.05 & 6.87 & 8.39 & 1.15 & 4.29 & 1.20 & 2.64 & 2.84 & 1.59 & 0.85 & 6.44 & 2.92 \\
\hline $\mathrm{MgO}$ & 0.13 & 2.69 & 4.14 & 0.19 & 1.42 & 0.21 & 0.50 & 0.81 & 0.18 & 0.09 & 3.36 & 0.69 \\
\hline $\mathrm{CaO}$ & 0.66 & 5.55 & 6.63 & 0.68 & 4.10 & 0.74 & 1.30 & 2.16 & 0.76 & 0.54 & 7.33 & 1.78 \\
\hline $\mathrm{Na}_{2} \mathrm{O}$ & 3.45 & 4.07 & 2.82 & 2.63 & 3.27 & 3.54 & 3.50 & 3.50 & 2.52 & 3.54 & 3.95 & 3.56 \\
\hline $\mathrm{K}_{2} \mathrm{O}$ & 4.32 & 2.15 & 1.78 & 4.51 & 2.59 & 4.17 & 3.80 & 3.79 & 5.05 & 4.34 & 1.41 & 4.07 \\
\hline $\mathrm{TiO}_{2}$ & 0.05 & 1.10 & 1.20 & 0.08 & 0.65 & 0.11 & 0.30 & 0.35 & 0.16 & 0.04 & 1.01 & 0.43 \\
\hline $\mathrm{P}_{2} \mathrm{O}_{5}$ & 0.08 & 0.44 & 0.46 & 0.08 & 0.19 & 0.04 & 0.10 & 0.11 & 0.05 & 0.03 & 0.24 & 0.13 \\
\hline $\mathrm{MnO}$ & 0.10 & 0.09 & 0.13 & 0.04 & 0.06 & 0.05 & 0.05 & 0.04 & 0.02 & 0.07 & 0.07 & 0.03 \\
\hline $\mathrm{Cr}_{2} \mathrm{O}_{3}$ & 0.00 & 0.00 & 0.01 & 0.00 & 0.00 & 0.00 & 0.00 & 0.00 & 0.00 & 0.00 & 0.00 & 0.01 \\
\hline LOI & 0.60 & 0.50 & 0.80 & 0.90 & 0.80 & 0.20 & 0.60 & 0.80 & 0.70 & 1.20 & 1.40 & 1.40 \\
\hline TOT_C & 0.01 & 0.01 & 0.01 & 0.01 & 0.01 & 0.01 & 0.01 & 0.01 & 0.03 & 0.04 & 0.03 & 0.10 \\
\hline Total & 99.92 & 99.54 & 99.52 & 99.81 & 99.63 & 99.83 & 99.77 & 99.70 & 99.81 & 99.86 & 99.69 & 99.82 \\
\hline
\end{tabular}

Abundances of the major oxides were analysed by ICP-emission spectrometry in ACME Laboratories, Canada. Loss on ignition (LOI) was calculated by weight difference after ignition at $1000^{\circ} \mathrm{C}$.

far less enriched in $\mathrm{Rb}$, with $\mathrm{Rb} / \mathrm{Sr}$ ratios of $0.06-0.60$; only one sample has $\mathrm{Rb} / \mathrm{Sr}=1.3$. The REE concentrations are similar to granites in their low values, from 86 to 180 . The LREE are moderately fractionated $\left(\mathrm{La}_{\mathrm{N}} / \mathrm{Sm}_{\mathrm{N}}=\right.$ 2.3-6.7). The HREE show a weak fractionation $\left(\mathrm{Gd}_{\mathrm{N}} / \mathrm{Yb}_{\mathrm{N}}\right.$ $=1.4-2.7)$. The Eu anomalies in these rocks are weak or absent (Fig. 3f). In NMORB-normalized spider diagrams, there is a distinct depletion in $\mathrm{Nb}$ and $\mathrm{P}$, and a slight depletion in Ti. This diagram also indicates a pronounced enrichment in $\mathrm{Cs}$ and $\mathrm{K}$, and a slight enrichment in Th and $\mathrm{Nd}$. The $\mathrm{Ba}, \mathrm{Pb}$ and $\mathrm{Sr}$ show complex trends for felsic and intermediate rocks (Fig. 3e). Rocks of the metaluminous group fall into the Volcanic Arc Granite (VAG) field in the Pearce et al. (1984) classification scheme (Fig. 4b-c).

\subsection{Mineral composition and thermobaro- metric analysis}

Analysis of mineral major oxide composition for the aluminum-in-hornblende igneous barometer (Hammastrom and Zen 1986; Hollister et al. 1987) was conducted on a JEOL JXA-8200 electron microprobe at the University of California, Los Angeles. Samples were analyzed in spot mode with a beam current of $15 \mathrm{nA}$ and accelerating voltage of $15 \mathrm{kV}$. One $\sigma$ analytical error is $1 \%$. Two samples from dioritic units were selected based on the presence of the appropriate mineral assemblage, including amphibole, quartz, K-feldspar, titanite, and magnetite. These samples were doubly polished, cleaned and sputter coated with graphite. Major oxides were analyzed for plagioclase, hornblende, biotite and Fe-Ti oxide minerals. Plagioclase and hornblende analyses were used to apply the Al-in-Hbl barometer and the plagioclase-hornblende thermometer (Blundy and Holland 1990) in order to constrain conditions of crystallization of dioritic plutons (Fig. 5a-b). Analysed were conducted on adjacent plagioclase and hornblende grains that were each touching a quartz grain to ensure silica saturation at the last phase of crystallization (Fig. 5d). Transects from core to rim of both the plagioclase and hornblende grains were conducted, and additional analyses of each crystal on its rim against quartz were also obtained. The goal of these transects was to constrain both the crystallization history of the sample and the thermobarometric conditions at the final stages of crystallization, represented by analyses on sample rims. To constrain secular variation, three plagioclase-hornblende pairs were analyzed for each sample. Pressures stated are corrected for temperature according to the formulation of Anderson and Smith (1995).

Sample 204 displays complexly zoned hornblende crystals that yield an average rim crystallization of $2.9 \pm$ 0.5 kbars ( $1 \sigma$ combined analytical and statistical errors) (Fig. 5a). Based on a pressure gradient of $3.7 \mathrm{~km}$ per kbar (based on a crustal density of $2.7 \mathrm{~g} / \mathrm{cm}^{3}$ ), these rocks crystallized at c. $11 \mathrm{~km}$. Anorthite content of plagioclase in this sample varies from 30 to $40 \%$. Rim crystallization temperatures are calculated as $756 \pm 23{ }^{\circ} \mathrm{C}$. 
Tab. 1b Whole-rock trace-element analyses (ppm) for igneous rocks of the Chandman Massif

\begin{tabular}{|c|c|c|c|c|c|c|c|c|c|c|c|c|}
\hline $\begin{array}{l}\text { Sample } \\
\text { Rock }\end{array}$ & $\begin{array}{l}\text { H0168 } \\
\text { granite }\end{array}$ & $\begin{array}{l}\text { H0239 } \\
\text { granite }\end{array}$ & $\begin{array}{l}\text { H0332 } \\
\text { diorite }\end{array}$ & $\begin{array}{l}\text { H0333 } \\
\text { granite }\end{array}$ & $\begin{array}{l}\text { H0337 } \\
\text { diorite }\end{array}$ & $\begin{array}{l}\text { H0338 } \\
\text { granite }\end{array}$ & $\begin{array}{l}\text { H0339 } \\
\text { granite }\end{array}$ & $\begin{array}{l}\text { H0341 } \\
\text { diorite }\end{array}$ & $\begin{array}{l}\text { H0549 } \\
\text { granite }\end{array}$ & $\begin{array}{l}\text { H0551 } \\
\text { granite }\end{array}$ & $\begin{array}{l}\text { R0405 } \\
\text { diorite }\end{array}$ & $\begin{array}{c}\text { Z0992 } \\
\text { granodiorite }\end{array}$ \\
\hline $\mathrm{Ba}$ & 119.2 & 419.6 & 404.4 & 174.3 & 457.1 & 264.9 & 524.4 & 648.6 & 472.5 & 46.6 & 369.9 & 1305.0 \\
\hline Co & 0.8 & 18.0 & 27.6 & 1.0 & 9.2 & 1.3 & 4.0 & 5.8 & 2.4 & 0.6 & 21.9 & 5.5 \\
\hline Cs & 8.6 & 6.4 & 1.9 & 4.4 & 2.7 & 1.3 & 2.8 & 5.0 & 1.4 & 5.1 & 6.2 & 1.7 \\
\hline Ga & 21.4 & 23.7 & 20.8 & 17.8 & 19.1 & 16.2 & 17.6 & 17.9 & 12.6 & 21.2 & 23.4 & 15.7 \\
\hline $\mathrm{Hf}$ & 2.4 & 6.6 & 5.4 & 1.9 & 5.2 & 3.1 & 5.9 & 4.9 & 2.9 & 2.1 & 4.1 & 6.8 \\
\hline $\mathrm{Nb}$ & 32.0 & 12.2 & 14.9 & 19.1 & 12.5 & 16.4 & 13.5 & 10.1 & 3.5 & 32.2 & 7.6 & 9.0 \\
\hline $\mathrm{Rb}$ & 244.9 & 93.9 & 66.9 & 173.3 & 100.0 & 131.6 & 136.4 & 132.8 & 88.0 & 240.8 & 51.0 & 65.1 \\
\hline Sn & 2 & 2 & 3 & 2 & 2 & 1 & 3 & 2 & 1 & 6 & 1 & 1 \\
\hline $\mathrm{Sr}$ & 28.6 & 628.0 & 382.1 & 50.3 & 316.5 & 95.8 & 131.3 & 204.5 & 67.5 & 20.1 & 798.5 & 278.0 \\
\hline Тa & 3.8 & 1.7 & 0.9 & 2.5 & 1.1 & 1.8 & 1.3 & 1.0 & 0.3 & 7.9 & 0.4 & 0.6 \\
\hline Th & 6.7 & 7.3 & 4.4 & 7.2 & 13.5 & 12.7 & 15.1 & 14.6 & 14.8 & 10.6 & 4.8 & 6.5 \\
\hline $\mathrm{U}$ & 1.3 & 3.5 & 1.2 & 1.6 & 2.6 & 1.5 & 2.2 & 2.3 & 0.8 & 2.7 & 1.4 & 1.3 \\
\hline V & - & 114 & 173 & 6 & 74 & 10 & 22 & 37 & 10 & 7 & 158 & 29 \\
\hline W & 0.5 & 0.4 & 0.1 & 2.4 & 0.1 & 0.3 & 0.1 & 0.1 & 0.2 & 1.3 & 0.5 & 0.2 \\
\hline $\mathrm{Zr}$ & 48.6 & 265.5 & 226.7 & 45.5 & 185.5 & 66.4 & 201.9 & 162.7 & 94.5 & 31.3 & 153.8 & 267.9 \\
\hline Y & 25.8 & 29.7 & 29.0 & 21.9 & 21.9 & 17.7 & 24.5 & 23.4 & 8.1 & 21.5 & 13.7 & 17.9 \\
\hline Mo & 0.2 & 0.2 & 0.3 & 0.2 & 0.3 & 0.2 & 0.3 & 0.3 & 0.3 & 0.2 & 0.2 & 0.2 \\
\hline $\mathrm{Cu}$ & 6.3 & 32.2 & 53.0 & 6.9 & 19.6 & 4.6 & 5.8 & 6.8 & 15.2 & 4.4 & 47.8 & 6.1 \\
\hline $\mathrm{Pb}$ & 1.7 & 1.0 & 1.1 & 2.8 & 1.6 & 6.6 & 6.4 & 4.3 & 6.7 & 8.7 & 1.6 & 3.2 \\
\hline $\mathrm{Zn}$ & 9 & 68 & 61 & 13 & 49 & 21 & 40 & 38 & 17 & 4 & 45 & 35 \\
\hline $\mathrm{Ni}$ & 2.2 & 17.5 & 49.9 & 2.1 & 6.9 & 2.8 & 4.8 & 8.0 & 4.1 & 2.2 & 17.0 & 4.4 \\
\hline As & 0.5 & 0.5 & 0.8 & 0.6 & - & - & 0.8 & 0.6 & 0.9 & - & 0.8 & 0.5 \\
\hline Cd & 0.1 & - & - & - & - & - & - & - & - & - & - & - \\
\hline $\mathrm{Sb}$ & - & - & - & - & - & 0.1 & 0.1 & - & - & - & - & - \\
\hline $\mathrm{Bi}$ & 0.1 & 0.1 & - & 0.2 & - & - & - & - & 0.1 & 0.1 & - & - \\
\hline $\mathrm{Au}$ & 1.4 & - & 1.1 & 0.9 & - & 0.7 & - & 0.7 & 2.1 & 3.1 & 1.2 & 4.3 \\
\hline $\mathrm{La}$ & 10.0 & 33.4 & 25.2 & 11.3 & 37.8 & 15.6 & 34.5 & 29.5 & 35.5 & 7.0 & 22.9 & 41.7 \\
\hline Ce & 22.9 & 66.9 & 62.5 & 25.1 & 79.5 & 32.5 & 72.5 & 62.8 & 72.5 & 17.2 & 50.3 & 86.7 \\
\hline $\operatorname{Pr}$ & 2.52 & 7.46 & 7.55 & 2.68 & 8.44 & 3.52 & 7.51 & 6.33 & 6.81 & 1.86 & 5.44 & 8.83 \\
\hline $\mathrm{Nd}$ & 10.1 & 33.0 & 34.3 & 10.4 & 31.7 & 12.7 & 28.4 & 23.7 & 23.9 & 7.6 & 21.7 & 32.5 \\
\hline $\mathrm{Sm}$ & 2.6 & 6.3 & 6.7 & 2.6 & 5.5 & 2.7 & 5.2 & 4.4 & 3.3 & 2.1 & 4.1 & 5.1 \\
\hline $\mathrm{Eu}$ & 0.27 & 1.57 & 1.57 & 0.38 & 1.24 & 0.44 & 0.93 & 0.99 & 0.65 & 0.15 & 1.36 & 1.32 \\
\hline $\mathrm{Gd}$ & 3.23 & 5.22 & 6.02 & 2.80 & 4.63 & 2.19 & 4.67 & 4.08 & 2.21 & 2.57 & 3.50 & 3.69 \\
\hline $\mathrm{Tb}$ & 0.69 & 0.79 & 0.86 & 0.50 & 0.65 & 0.38 & 0.66 & 0.60 & 0.27 & 0.58 & 0.47 & 0.61 \\
\hline Dy & 3.97 & 4.29 & 5.03 & 3.35 & 3.69 & 2.61 & 4.34 & 3.86 & 1.54 & 3.55 & 2.70 & 3.26 \\
\hline Но & 0.86 & 0.89 & 1.06 & 0.66 & 0.76 & 0.52 & 0.83 & 0.74 & 0.24 & 0.65 & 0.47 & 0.57 \\
\hline Er & 2.46 & 2.64 & 2.70 & 1.80 & 1.97 & 1.64 & 2.47 & 2.14 & 0.70 & 1.93 & 1.37 & 1.64 \\
\hline $\mathrm{Tm}$ & 0.38 & 0.41 & 0.39 & 0.29 & 0.29 & 0.23 & 0.37 & 0.32 & 0.12 & 0.30 & 0.18 & 0.23 \\
\hline $\mathrm{Yb}$ & 3.04 & 2.94 & 2.54 & 2.35 & 1.90 & 1.76 & 2.90 & 2.39 & 0.66 & 2.10 & 1.25 & 1.44 \\
\hline $\mathrm{Lu}$ & 0.40 & 0.44 & 0.34 & 0.33 & 0.28 & 0.25 & 0.39 & 0.32 & 0.11 & 0.28 & 0.18 & 0.21 \\
\hline REE & 63.42 & 166.25 & 156.76 & 64.54 & 178.35 & 77.04 & 165.67 & 142.17 & 148.51 & 47.87 & 115.92 & 187.80 \\
\hline
\end{tabular}

The rare earth and most remaining trace elements were analysed in ACME Laboratories, Canada by INAA and ICP-MS following a LiBO ${ }_{2}$ fusion; the precious and base metals were analysed by aqua regia digestion/ICP-MS.

Sample 126 displays an average rim pressure of $3.7 \pm$ 0.5 kbars (Fig. 5b), representing a crystallization depth of $13.7 \mathrm{~km}$. An average of core analyses yields $2.8 \pm 0.2$ kbars. This pattern is antithetical to the simple scenario where, in an ascending magma, the crystal rims preserve the lowest pressures. This may suggest that hornblende crystals grew at the expense of pyroxene or indicate that core compositions are not representative of equilibrium 


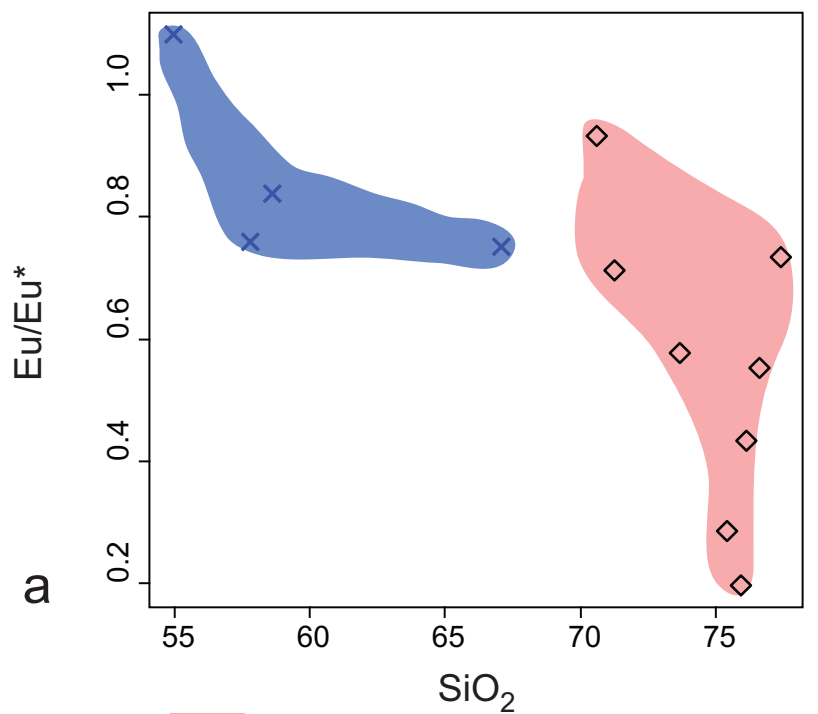

$\diamond \quad$ Peraluminous samples

$\times \quad$ Metaluminous samples
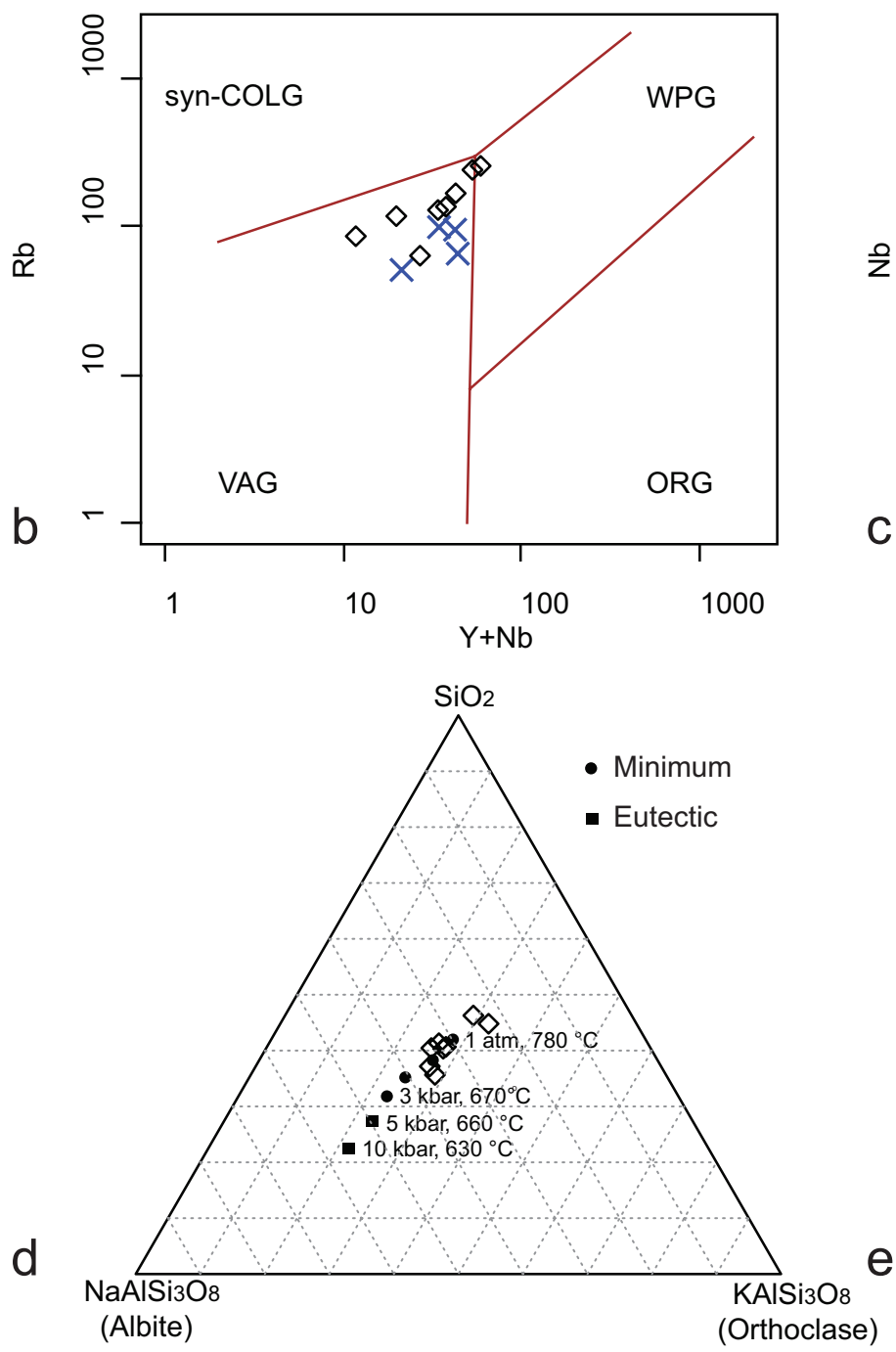

Fig. 4 Geochemistry of the Chandman Massif II. a - Further demonstration of separation of units by $\mathrm{SiO}_{2}$ vs. Eu/Eu* diagram, b-c geotectonic classification plots (Pearce et al. 1984) both demonstrating the Volcanic Arc to Within Plate character of the Chandman Massif plutons, d - Ab-Qtz-Or (CIPW norm with $\mathrm{Hbl}$ ) ternary diagram with eutectic and cotectic points for granites at several depths shown (Johannes and Holtz 1996 and references therein), e - CaO/ $\mathrm{Na}_{2} \mathrm{O}$ vs. $\mathrm{Al}_{2} \mathrm{O}_{3} / \mathrm{TiO}_{2}$ classification for magmatic rocks with sedimentary and igneous sources (shaded gray area, field of strongly peraluminous granites) after Sylvester (1998).
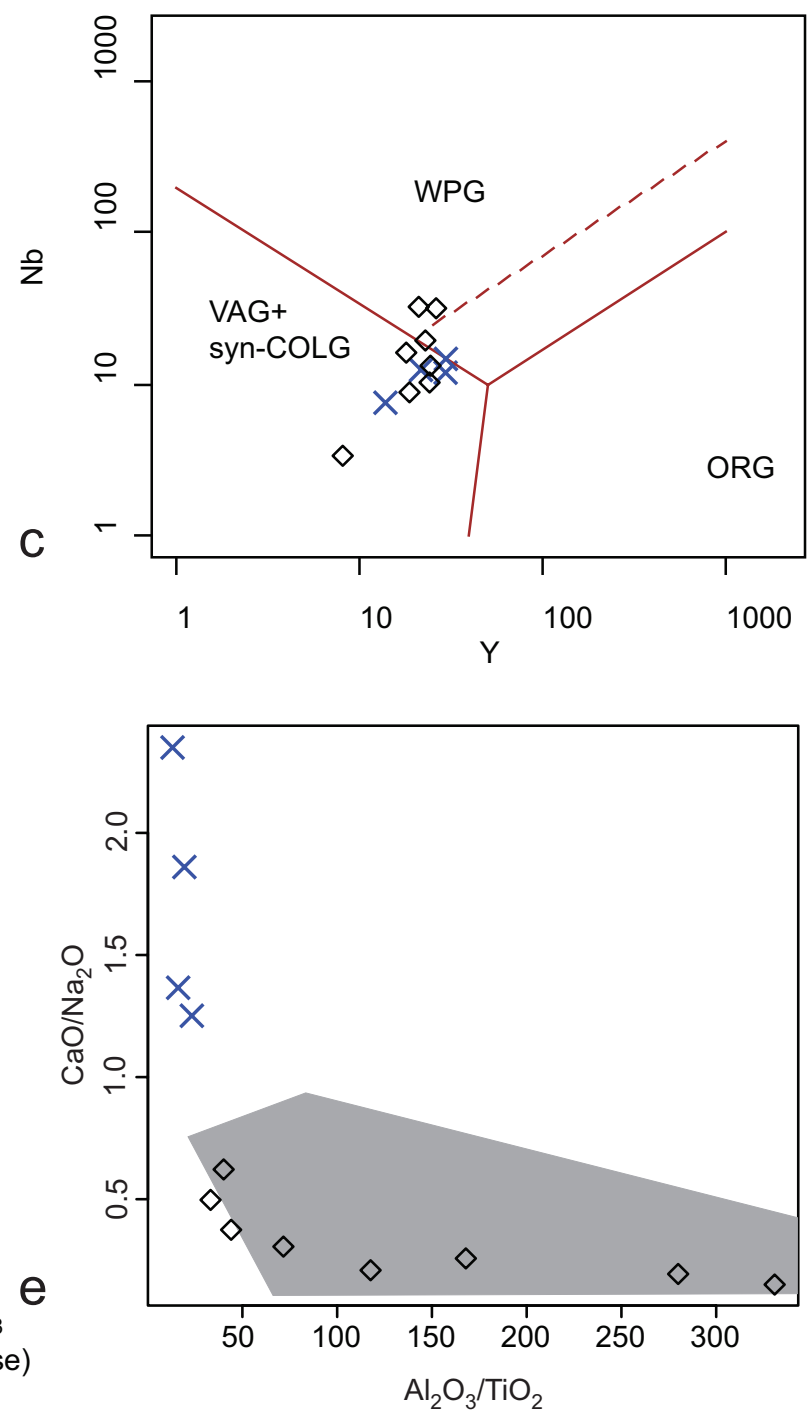
a

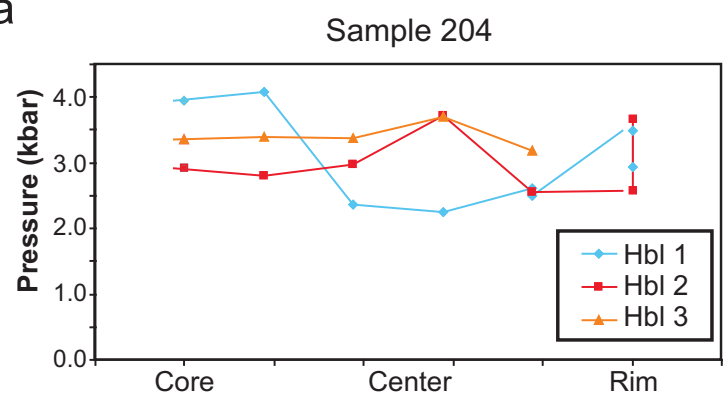

C

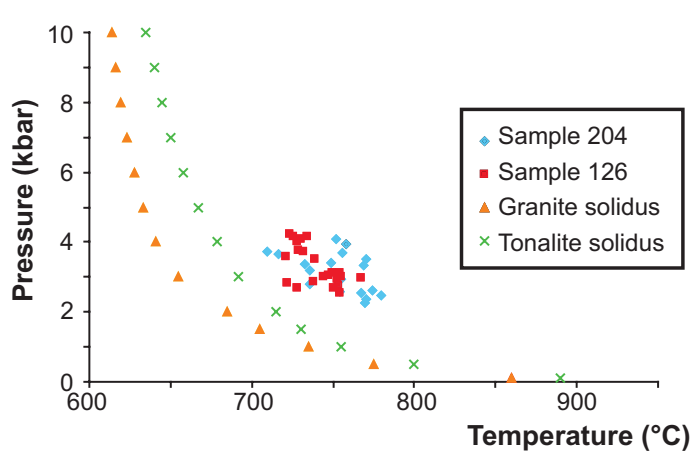

b

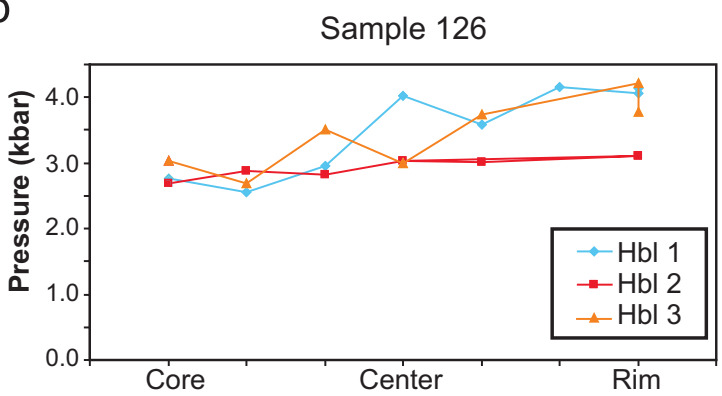

d
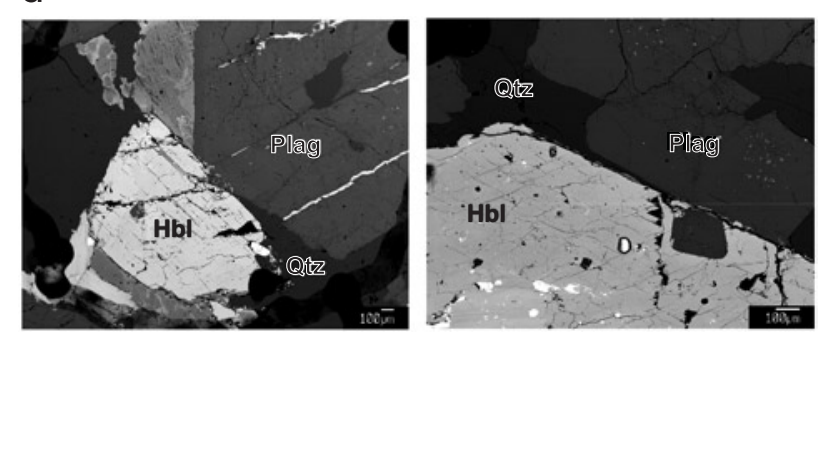

Fig. 5 Thermobarometric analysis of two samples: a-b results of Al-in-hornblende geobarometry (Holland and Blundy 1994 calibration). Transects from cores to rims of companion feldspars and hornblendes demonstrate relatively homogeneous composition and show a slight reverse zoning of sample 126, c - P-T conditions based on Al-in-hornblende barometry (Holland and Blundy 1994; Anderson and Smith 1995) and plagioclase-hornblende thermometry (Blundy and Holland 1990 calibration) compared to the granite and tonalite solidi (Luth et al. 1964; Piwinskii 1968), and d - backscattered electron images of analyzed companion feldspar and hornblende grains in contact with quartz.

crystallization. Estimated temperature for this sample is $740 \pm 14{ }^{\circ} \mathrm{C}$. In P-T space, these samples plot well above the tonalite solidus (Fig. $5 \mathrm{c}$ ). Anorthite content of plagioclase in this sample varies from 25 to $32 \%$.

Further barometric constraint is provided by several dioritic and granodioritic samples that contain magmatic epidote. Igneous epidote has been shown to exist at a minimum pressure of 4-6 kbars (Schmidt 1983; Zen and Hammastrom 1984; Schmidt and Poli 2004). Magmatic epidotes are found in the northern portion of the field area, near the contact between diorites and the Chandman Khayrkhan Crystalline Complex. This stability field translates to a minimum of 15-20 km for emplacement of diorites based on a barometric gradient of $3.7 \mathrm{~km}$ per kbar.

\subsection{U-Pb LA-ICP-MS zircon dating}

Zircons from a dioritic sample were analyzed for U-Pb geochronology (Hrdličková et al. 2008). Thirty-two U-Pb spot analyses were carried out on 26 grains by LA-ICPMS at the Institute of Geosciences, Johann-WolfgangGoethe-University, Frankfurt. Zircons displayed igneous textures including long prismatic crystal habit. Cathodolu- minescence images revealed fine igneous oscillatory crystal zoning: no discordant cores were identified. Continuous zoning from core to rim documents only one phase of zircon growth, which is in line with the U-Pb analyses. Twenty-five spot analyses yielded concordant results with a concordia age of $345 \pm 2 \mathrm{Ma}(2 \sigma)$. Additional analytical details are available in Hrdličková et al. (2008).

\section{Structural data}

\subsection{General structure}

Satellite images of the Chandman Massif reveal a fault that trends $\sim 330^{\circ}$ that dissects the Chandman Massif into a northern and southern section (Fig. 1). Orientations of structures display a marked difference to the north and south of this fault (Fig. 6).

Metamorphic foliation in host rocks, rafts and blocks is the oldest foliation in the complex and displays some variation. The northern domain of the complex displays strikes toward $\sim 345^{\circ}$ while the southern domain has strong maxima towards $\sim 330^{\circ}$. Both foliations are moderately to steeply dipping towards the NNE (Fig. 6a). 
Metamorphic Foliations (host and blocks)

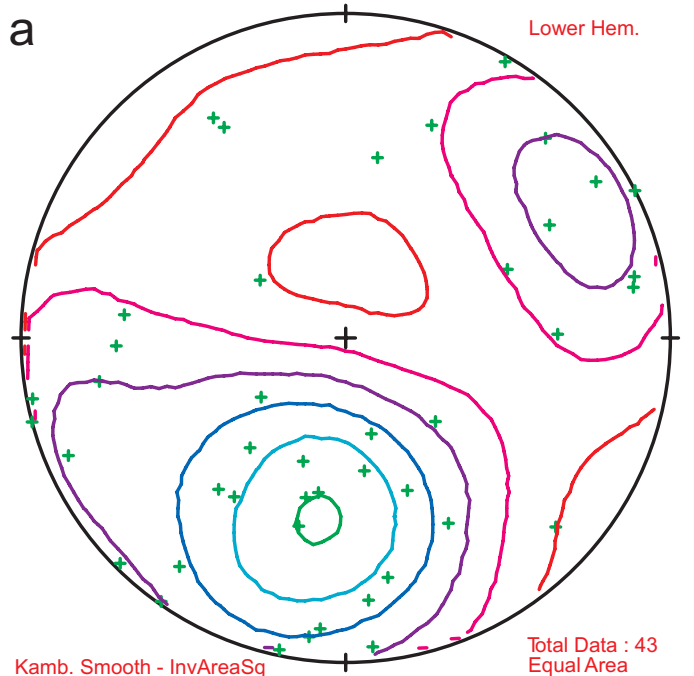

Magmatic Fabrics (all units)
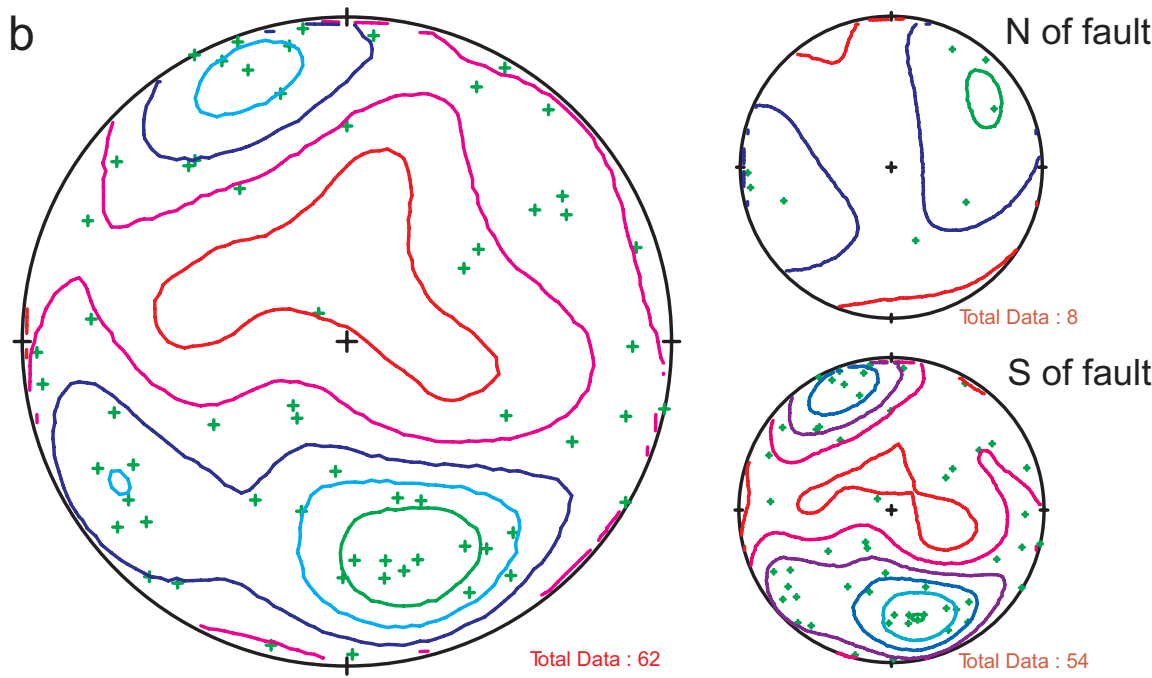

\section{Solid-state Foliation (in plutons)}
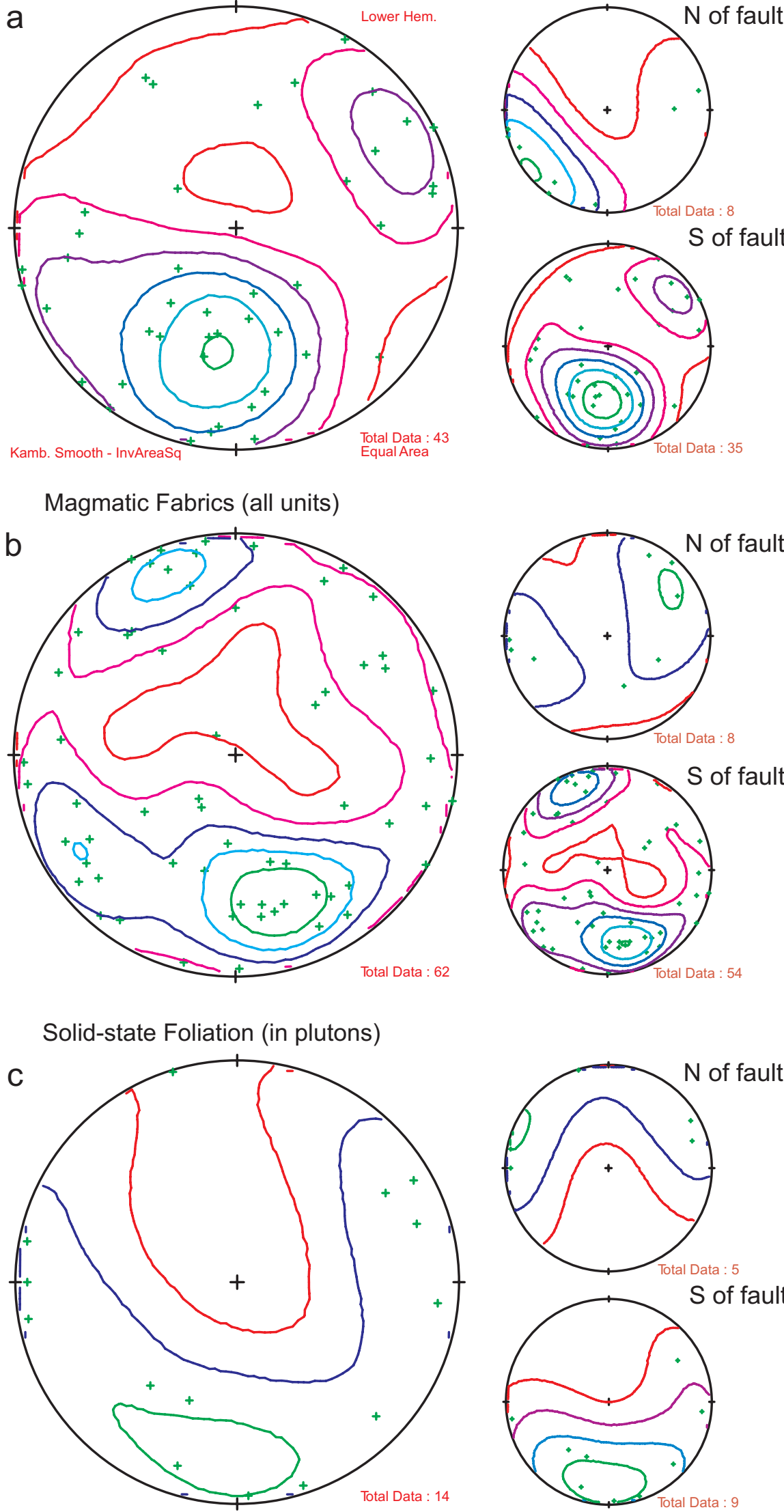

$S$ of fault

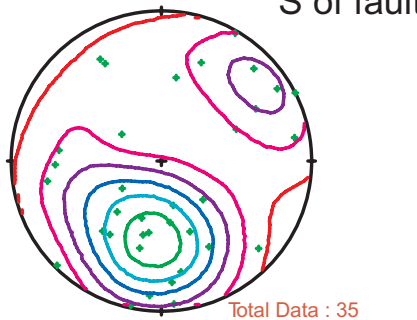

.




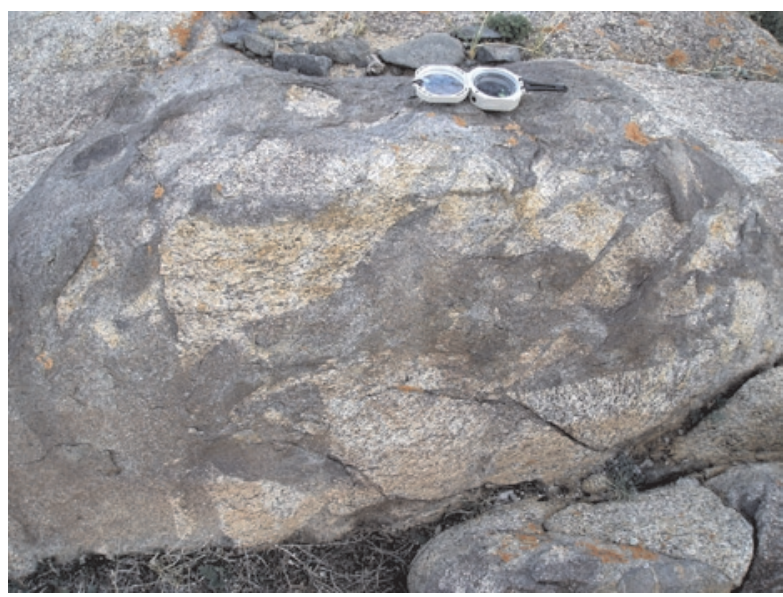

a

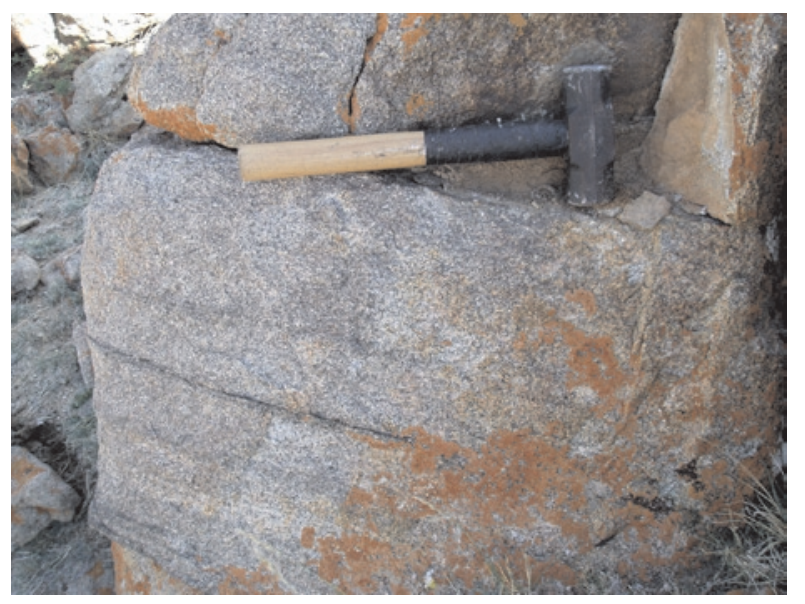

C

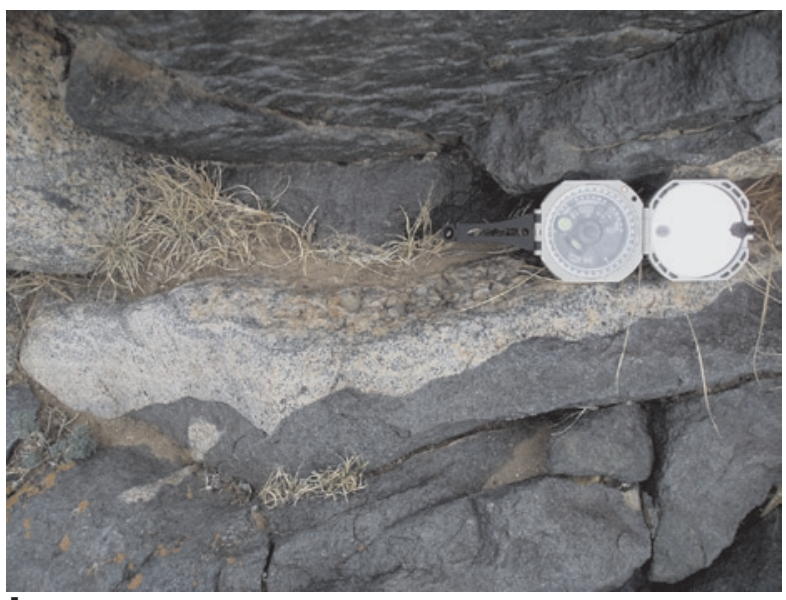

b

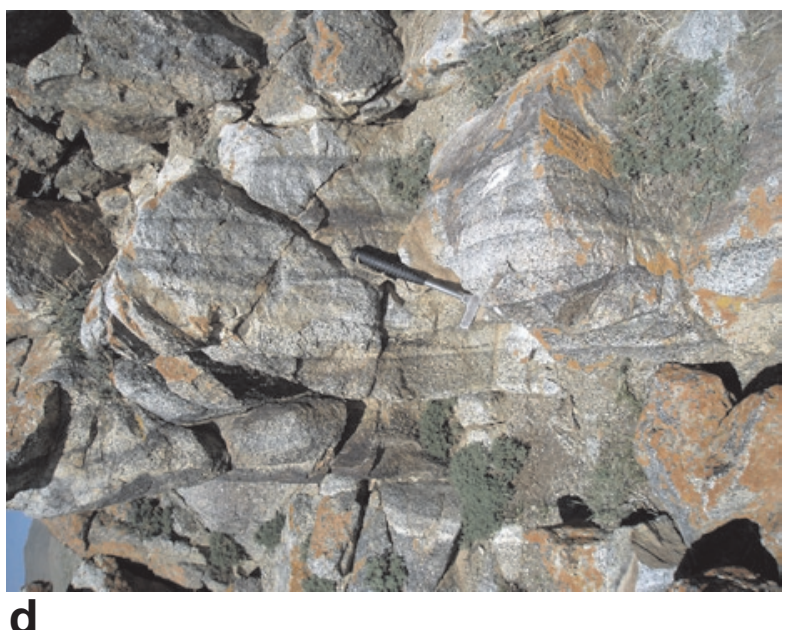

Fig. 7 Field photographs of magmatic structures in plutons: a-b field evidence for the coeval intrusion of granites and diorites, $\mathbf{c}-\mathbf{d}$ enigmatic rhythmic schlieren layering common in granodioritic units.

for the Main Donegal Pluton, there are no minerals with metamorphic textures in these layers. Petrographically, these layers consist of accumulation of only biotite and apatite. Thus, the mechanism for formation of these structures remains enigmatic.

Magmatic fabrics were defined by the statistical alignment of minerals with high axial ratios, particularly biotite in granites and biotite and hornblende in granodiorites to diorites. In granodioritic and dioritic units, elongate mafic enclaves are often aligned with the magmatic foliation. Magmatic foliation represents strain potentially caused by several processes, including margin effects, local flow, and strain from tectonic forces (Paterson et al. 1998). Thus, it is not surprising that measured magmatic foliations show a moderate amount of scatter. However, clear differences in maxima are seen to the north and south of the fault. North of this structure, steeply dipping, roughly N-S oriented magmatic fabrics are observed. To the south of the fault, magmatic foliations are oriented roughly E-W and are also steeply dipping (Fig. 6b).
Dioritic units also contain schlieren, but this layering is rarer and more complex in geometry. Discontinuous schlieren are found particularly along contacts with metamorphic host-rock blocks. This layering displays trough-like structures with crystal size sorting along trough bottoms, similar in appearance to sedimentary graded bedding. These structures suggest, according to Barrière (1981), that crystal deposition and magmatic scouring and flow-sorting occurred during magmatic flow (Fig. 7b).

Solid-state foliations in plutons were defined in the field by observable elongation of quartz grains and occasionally folding of earlier magmatic foliations (Fig. 8a). In the southern portion of the complex, solid-state foliations are found only at scattered outcrops spaced over several tens to several hundreds of meters. Effects of solid-state deformation become more widespread toward the north, and are ubiquitous on the SW slopes of the Chandman Khayrkhan Mountain. As the foliation becomes more pervasive, it also increases in intensity. 
These foliations again show distinct orientations in northern and southern portions of the Massif. These orientations are in excellent agreement with magmatic fabrics, with those to the north striking roughly N-S and those to the south striking roughly E-W (Fig. 6c).

\subsection{Structures in migmatites}

Migmatites throughout the Chandman Khayrkhan Crystalline Complex display a wide range of structures. Lit-par-lit style migmatization is defined by leucosome and melanosome layering, for example in the core of the Chandman Khayrkhan Mountain (Fig. 8b-c). Here, leucosomes form discontinuous elongate bodies, generally $\mathrm{cm}$ to $\mathrm{dm}$ in length, and all structures are parallel to the foliation in metamorphic rocks. These concordant stromatic migmatites grade into a more diatectic structural style, where leucosomes cross-cut and disrupt schist foliation (Fig. 8c). Here leucosomes comprise a larger total percentage of rocks and form continuous interconnected melt networks. In outcrops where leucosome dominates, melanocratic material becomes highly disrupted and can achieve a rounded or ellipsoidal shape.

Near the margins of the Chandman Khayrkhan Mountain, where schists are intruded by diorites and granites, leucosomes make up approximately $20 \%$ of the rock. Gradational contacts with granites in these localities suggest that migmatitic material contaminated granite intrusions. Such localities often display gradational contacts with adjacent granodiorites and granites where physical contamination of granitoids is observed in the form of small fragments of melanosome/restite encased in the intruding bodies. In many instances, dikes with sharp contacts are observed cross-cutting these structures. However, in some localities, leucosomes grade into intruding magmas at fine scales. While these structures do not rule out that migmatization occurred prior to the intrusion of the Chandman Massif, they do indicate that, at least in part, the heat of these intrusions contributed to local melting and contamination of the magmas.

\section{Discussion}

Intrusive relationships indicate that units of the peraluminous and metaluminous suites of the Chandman Massif formed (nearly) contemporaneously. While the majority of cross-cutting relationships show the Chandman granites as younger than granodiorites, rare outcrops with cuspate-lobate margins and mutually intrusive contacts suggest that these units are nearly co-magmatic. However, even in these areas, no effects of mixing or

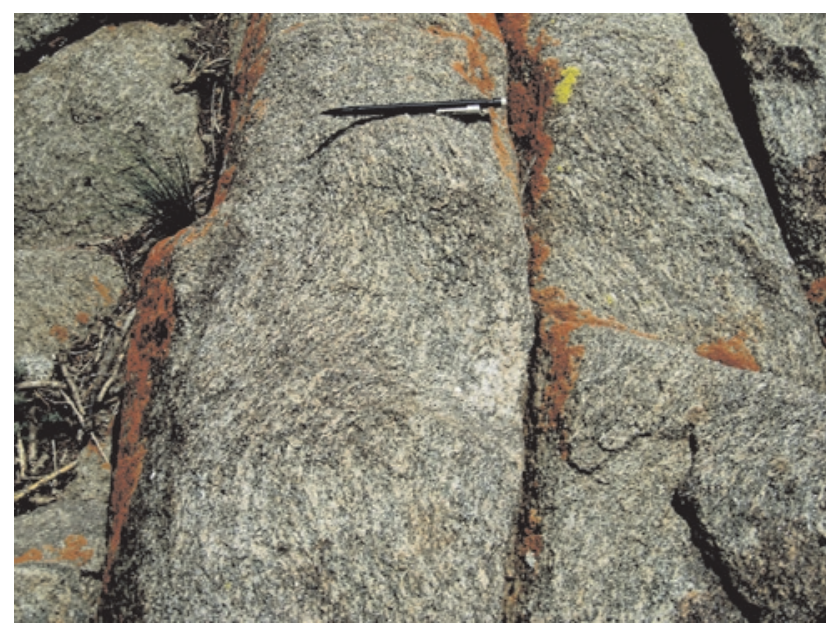

a

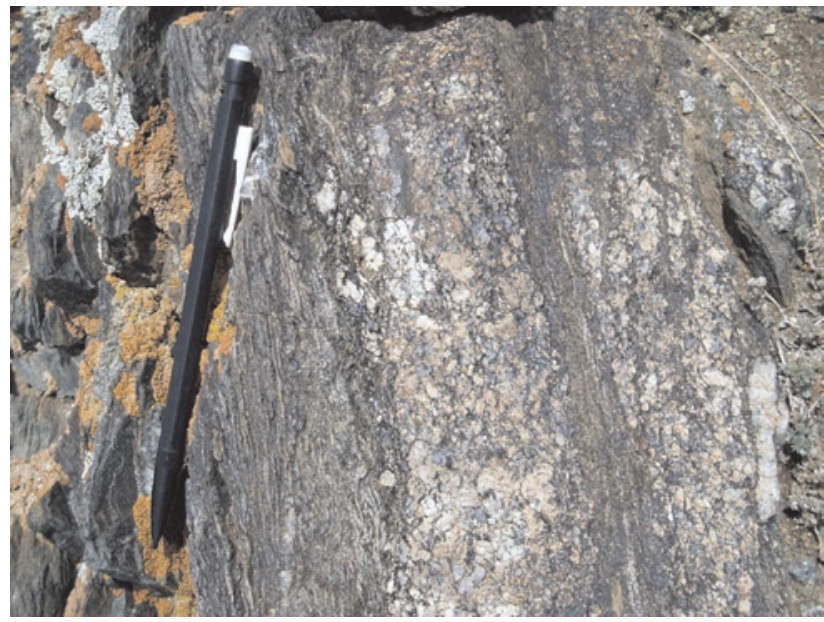

b

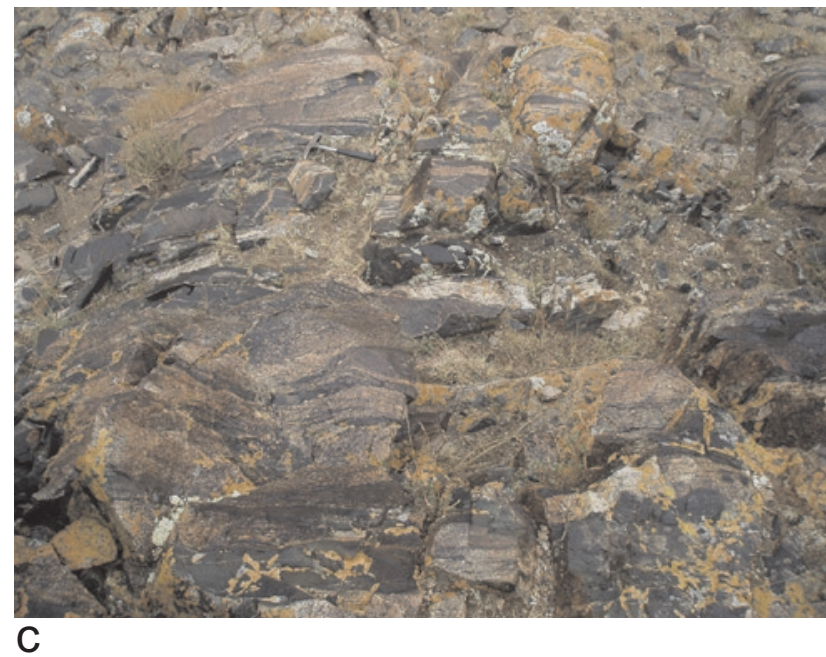

Fig. 8 Field photographs of post-magmatic structures in plutons and wall rocks, a - solid-state foliation folding of the earlier magmatic fabrics, b - lit-par-lit or stromatic migmatites, $\mathbf{c}$ - diatectic migmatites. 
hybridization are observed. Compositional variation at the intrusive contacts between these two magma types suggests a significant viscosity contrast, which could have prevented hybridization.

While peraluminous granites are closely spatially related to migmatites, it is unlikely that migmatites at the level of exposure were the main source material for these plutons. At the relatively shallow level of intrusion of these granites, only a very small percent of partial melting would be possible without a significant input of a surplus heat. Based on hornblende-plagioclase thermometry and the presence of magmatic epidote, melting of fertile materials at the emplacement level would be likely, but the large amount of schist needed to generate voluminous peraluminous plutons is lacking in the Chandman Khayrkhan Crystalline Complex. Thus, contamination from local migmatites could account for only a small portion of the volume of Chandman granites exposed here. In addition, in Qtz-Or-An space (Fig. 4d), Chandman granites are evolved away from eutectic compositions for melting at 3-3.5 kbars, which could be evidence of fractionation during ascent. These data are consistent with the bulk of Chandman peraluminous granites having a source below the level now exposed. Thus, although the Chandman Massif peraluminous granites have some connection to the adjacent migmatite terrane, a larger body, not presently exposed, must be responsible for the bulk of the peraluminous material seen in the Chandman Massif.

Metaluminous rocks of the Chandman Massif display calc-alkaline geochemical trends and are of magnetite series, indicating crystallization from highly oxidized magmas (Ishihara 1977). They contain a high percentage of hydrous minerals, particularly hornblende, and fall within the volcanic arc geochemical field. Based on this evidence, we suggest that these plutons were generated in a subduction regime. The temporally overlapping, but slightly delayed, emplacement of peraluminous granites with respect to the metaluminous magmas suggests that the intrusion of more mafic units could have initiated partial melting of country rock during their ascent and/or emplacement.

Finally, the excellent agreement of magmatic and solid-state foliations suggests that the tectonic forces responsible for generating the strong magmatic fabric in the massif continued to influence these rocks after crystallization - we are unsure as to the cause of increased pervasiveness of solid-state foliation toward the Chandman Khayrkhan Mountain. The present discordance of metamorphic foliations, magmatic foliations, and solidstate fabrics to the north and south of the central fault suggests that it was active late in the evolution of the complex, possibly as a secondary Riedel Fault related to recent motion on the Bogd Fault along the northern margin of the massif.

Compilation of all available datasets suggests that this area experienced amphibolite-facies metamorphism of the Chandman Khayrkhan Crystalline Complex, exhumation to mid-crustal levels, and juxtaposition against the greenschist-facies Tugrug Formation. The Crystalline Complex was then intruded by metaluminous and peraluminous plutons of the Chandman Massif. These data correlate well with the findings of Hrdličková et al. (2008), where a similar sequence of events (early migmatite generating metamorphism and later peraluminous granitic intrusion) was identified in the Unegt Uul Crystalline Complex. As no geochronological constraints on the age of migmatization are currently available for the Chandman Khayrkhan Crystalline Complex, a possibility of a shared evolution of the complexes cannot be assessed.

The Chandman Massif is shown here to be unique among the complexes presented in Hrdličková et al. (2008), in that it consists of dominantly metaluminous, amphibole-bearing units that fall clearly into the volcanic-arc field. These data thus indicate that the generation of the massif could not be due to crustal thickening and geothermal heating alone, but was mainly related to the subduction-related magmas. The Chandman Massif represents the first recognition of a volcanic-arc magmatism of Mississippian age in the western Gobi-Altay Terrane. The onset of Hercynian magmatism is suggested to be as early as $370 \mathrm{Ma}$, based on rocks from the Tseel Terrane (immediately to the west of the Chandman Massif area), which bear striking resemblance to those studied here. Kozakov et al. (2007) described plutons of mafic to plagiogranite compositions as well as granites and migmatites intruding biotite schists in many areas in the Tseel Terrane. Additional study is required in order to identify whether there is a relationship between Tseel Terrane units and the Chandman Massif, which may represent the easternmost extremity of the Hercynian arc.

Furthermore, the relationship between the Chandman Khayrkhan Crystalline Complex and Chandman Massif may be a direct evidence for the integration of pre-existing Caledonian materials into magmas of the Hercynian arc, suggested by isotopic evidence (Kovalenko et al. 2004). This situation calls for further work on the age of metamorphism within the crystalline complex and the isotopic systematics of both metamorphic and plutonic rocks. Such studies of central Mongolian granites, in concert with data presented here and by Hrdličková with her co-workers, will further our understanding of the complex transition from collision and crustal amalgamation to renewed magmatism (345 Ma) in Early Carboniferous times. 


\section{Conclusions}

Recent mapping of the Chandman Massif and its country rocks has led to the recognition of the Chandman Khayrkhan Crystalline Complex as having a separate protolith and metamorphic history from the Tugrug Formation. Structural, geochemical and thermobarometric evidence presented here suggests that the Chandman Khayrkhan Crystalline Complex is related to, but not representative for the entire source region of, the peraluminous granites in the Chandman Massif. The granitic rocks were classified into metaluminous and peraluminous units with distinctly different chemistries and subtly distinct petrographic characteristics. Our preferred interpretation of the two, roughly coeval, units is that they represent an evolution of volcanic-arc magmas, from diorite to granite, and partial melting of fertile sedimentary materials, triggered by their thermal input.

Mapping, petrography, geochemical and thermobarometric analyses all suggest a multi-phase history to migmatization of the Chandman Khayrkhan Crystalline Complex migmatites. Thermobarometry places constraints on the conditions of pluton emplacement to $11.5-13.7 \mathrm{~km}$ in the south, at least $15-20 \mathrm{~km}$ in the north and temperatures of $725-775{ }^{\circ} \mathrm{C}$. These estimates provide the necessary conditions for migmatization of gneisses of the Chandman Khayrkhan Mountain. However, field observations, geochemistry and petrography suggest that additional processes below the level of exposure largely contributed to migmatization and the generation of peraluminous plutons. The barometry and magmatic history also place constraints on the exhumation history of this migmatite terrane.

Our data point to a few local problems that require additional attention. For instance it remains unclear what mechanism juxtaposed of the Chandman Khayrkhan high-grade metamorphic rocks with greenschist-facies rocks of the Tugrug Formation. Any structure that would have accommodated this movement is now obscured by the Chandman Massif, but mapping of even greater detail of common host-rock septa in the complex could yield important constraints on such a structure. In addition, the mechanism for the formation of repetitive schlieren layering is enigmatic, but additional study could yield insights into internal processes that occurred during the construction of the Chandman Massif. Further geochronological and isotopic work in the area would supplement the available data that suggest that the evidence for initiation of Hercynian magmatism in Mississippian times is preserved in the Gobi-Altay Terrane.

Acknowledgements. Fieldwork was done during the project Geological survey of the Mongolian Altay on the scale 1: 50,000, which was performed in the framework of the
Program of the Development Cooperation Project of the Czech Republic. We are grateful to Mongolian staff of the expedition for participating in the fieldwork. We are indebted to J. Holák and Z. Novotný for the technical backing of geological survey. Funding was also provided by the Department of Earth Sciences at the University of Southern California. Our thanks extend to Viktor Kovach and an anonymous reviewer for their contributions to the manuscript.

Electronic supplementary material. The table with wholerock geochemical data (Tab. 1), tables with geobarometric determinations by the Al-in-hornblende method, as well as GPS coordinates of the studied samples, are available online at the Journal web site (http://dx.doi. org/10.3190/jgeosci.034).

\section{References}

Anderson JL (1996) Status of thermobarometry in granitic batholiths. Trans Roy Soc Edinb, Earth Sci 87: $125-138$

Anderson JL, Smith DR (1995) The effects of $\mathrm{fO}_{2}$ on the Alin-hornblende barometer. Amer Miner 80: 549-559.

Badarch G, Cunningham WD, Windley BF (2002) A new terrane subdivision for Mongolia: implications for the Phanerozoic crustal growth of central Asia. J Asian Earth Sci 20: 87-100

Baljinnyam I, Bayasgalan A, Borisov BA, Cisternas A, Dem'yanovich MG, Ganbaatar L, Kochetkov VM, Kurushin RA, Molnar P, Philip H, Vashchilov YY (1993) Ruptures of major earthquakes and active deformation in Mongolia and its surroundings. Geol Soc Am Memoir 181: pp 1-62

BARRIÈre M (1981) On curved laminae, graded layers, convection currents and dynamic crystal sorting in the Ploumanac'h (Brittany) subalkaline granite. Contrib Mineral Petrol 77: 214-224

Blundy JD, Holland TJB (1990) Calcic amphibole equilibria and a new amphibole-plagioclase geothermometer. Contrib Mineral Petrol 104: 208-224

Boynton WV (1984) Cosmochemistry of the rare earth elements: meteorite studies. In: HENDERSON PE (ed) Rare Earth Element Geochemistry. Elsevier, Amsterdam, pp 63-114

Cox KG, Bell JD, Pankhurst RJ (1979) The Interpretation of Igneous Rocks, George Allen \& Unwin, London, pp $1-450$.

Cunningham D (2005) Active intracontinental transpressional mountain building in the Mongolian Altai: defining a new class of orogen. Earth Planet Sci Lett 240: 436-444

Dergunov, AB (2001) Tectonics, Magmatism, and Metallogeny of Mongolia. Routledge, London, pp 1-288 
Hammarstrom JM, Zen E (1986) Aluminum in hornblende: an empirical igneous geobarometer. Amer Miner 71: 1297-1313

HanžL P, Aichler J (eds) (2007) Geological Survey of the Mongolian Altay at a scale 1 : 50,000 (Zamtyn Nuruu -50). Final report of the International Development Cooperation project of the Czech Republic. Czech Geological Survey, Brno \& MPRAM, Ulaanbaatar, pp 1-376

Holland TJB, Blundy JD (1994) Non-ideal interactions in calcic amphiboles and their bearing on amphiboleplagioclase thermometry. Contrib Mineral Petrol 116: 433-447

Hollister LS, Grissom GC, Peters EK, Stowell HH, Sisson VB (1987) Confirmation of the empirical correlation of $\mathrm{Al}$ in hornblende with pressure of solidification of calcalkaline plutons. Amer Miner 72: 231-239

Hrdlčková K, BolormaA K, Buriánek D, Hanžl P, Gerdes A, JANOUŠEK V (2008) Petrology and age of metamorphosed rock in tectonic slices inside the Palaeozoic sediments of the eastern Mongolian Altay, SW Mongolia. J Geosci 53: 139-165

Hu A, Jahn BM, Zhang G, Chen Y, Zhang Q (2000) Crustal evolution and Phanerozoic crustal growth in northern Xinjiang: Nd isotopic evidence. Pt 1. Isotopic characterization of basement rocks. Tectonophysics 328: 15-51

IRVINE TN, BARAGAR WR (1971) A guide to the chemical classification of the common volcanic rocks. Can J Earth Sci 8: 523-548

IsHIHARA, S (1977) The magnetite-series and ilmenite-series granitic rocks. Mining Geology 27: 293-305

JAHN BM, Wu F, CHen B (2000) Massive granitoid generation in Central Asia: Nd isotope evidence and implication for continental growth in the Phanerozoic. Episodes 23: 82-92

JAHN BM, Wu F, Chen B (2001) Granitoids of the Central Asian Orogenic Belt and continental growth in the Phanerozoic. Trans Roy Soc Edinb, Earth Sci 91: 181-193

Jahn BM, Capdevila R, Liu D, Vernon A, Badarch G (2004) Sources of Phanerozoic granitoids in the transect Bayanhongor-Ulaan Baatar, Mongolia: geochemical and Nd isotopic evidence, and implications for Phanerozoic crustal growth. J Asian Earth Sci 23: 629-653

Johannes W, Holtz, F (1996) Petrogenesis and Experimental Petrology of Granitic Rocks. Springer-Verlag, Berlin, pp 1-335

Kovalenko VI, Yarmolyuk VV, Kovach VP, Kotov AB, Kozakov IK, Salnikova EB, Larin AM (2004) Isotope provinces, mechanisms of generation and sources of the continental crust in the Central Asian mobile belt: geological and isotopic evidence. J Asian Earth Sci 23: 605-627

Kozakov IK, Kovach VP, Bibikova EV, Kirnozova TI, Zagornaya NY, Plotkina YV, Podkovyrov VN (2007) Age and sources of granitoids in the junction zone of the
Caledonides and Hercynides in southwestern Mongolia: geodynamic implications. Petrology 15: 126-150

Kröner A,Windley BF, Badarch G, Tomurtogoo O, Hegner E, Jahn BM, Gruschka S, Khain EV, Demoux A, Wingate MTD (2007) Accretionary growth and crust formation in the Central Asian Orogenic Belt and comparison with the Arabian-Nubian shield. In: HATCHER RD, Carlson MP, Mcbride JH, Martinez Catalan JR (eds) 4-D Framework of Continental Crust. Geol Soc Am Memoir 200: pp 181-209

Luth WC, Jahns RH, TuttLe OF (1964) The granite system at pressures of 4 to 10 kilobars. J Geophys Res 69: 759-773

Marinov NA, Zonenshain LP, Blagonravov VA (eds) (1973) Geologija Mongolskoi Narodnoi Respubliky. Nedra, Moscow, pp 1-582 (in Russian)

Molnar P, TAPPonnier P (1975) Cenozoic tectonics of Asia: effects of a continental collision: features of recent continental tectonics in Asia can be interpreted as results of the India-Eurasia collision. Science 189: 419-426

Mossakovsky AA, Ruzhentsev SV, Samygin SG, Kheraskova TN (1994) Central Asian fold belt; geodynamic evolution and formation history. Geotectonics 27: 445-474.

Paterson SR, Fowler TK, Schmidt KL, Yoshinobu AS, YuAN ES, MiLler RJ (1998) Interpreting magmatic fabrics in plutons. Lithos 44: 53-82

Pearce JA, Harris NW, Tindle AG (1984) Trace element discrimination diagrams for the tectonic interpretation of granitic rocks. J Petrol 25: 956-983

Peccerillo A, Taylor SR (1976) Geochemistry of Eocene calc-alkaline volcanic rocks from the Kastamonu area, Northern Turkey. Contrib Mineral Petrol 58: 63-81

Pitcher WS (1970) Ghost stratigraphy in intrusive granites: a review. In: Newall G, Rast N (eds) Mechanisms of Igneous Intrusion. Geol J Special Publication 2: 123-140

PIwINSKII AJ (1968) Experimental studies of igneous rock series: Central Sierra Nevada Batholith, California. J Geol 76: 548-570

Rauzer AA, Zhanchiv DI, Golyakov VI, YhHina IF, Ivanov IG, Tsukernik AB, Afonin VV, Smirnov IG, Bykhover VI, Kravtsev AV, BaAtarkhuyag A, Skoryukin MI, Khodikov, IV, Mantsev NV, OKaemov SV, Mischin VA, ENKHSAJKHAN T (1987) Report on results of geological mapping on scale 1:200,000 in the south-western part of Mongolian Altay in 1983-1983, Mongolian National Republic. Tekhnoexport, Moscow, pp 1-352 (in Russian)

Schmidt MW (1983) Phase relations and compositions in tonalite as a function of pressure: an experimental study at $650{ }^{\circ} \mathrm{C}$. Am J Sci 293: 1011-1060

Schmidt MW, Poli S (1983) Magmatic epidote. In: LieBSCHER A, Franz G (eds) Epidotes. Mineralogical Society of America and Geochemical Society Reviews in Mineralogy and Geochemistry 56: 399-430 
SEngör AC, Natal'in BA, Burtman VS (1993) Evolution of the Altaid tectonic collage and Paleozoic crustal growth in Eurasia. Nature 364: 299-306

SHAND SJ (1943) Eruptive Rocks. Their Genesis, Composition, Classification, and Their Relation to Ore-Deposits with a Chapter on Meteorite. $2^{\text {nd }}$ Edition. John Wiley \& Sons, New York, pp 1-444

Sun S-s, McDonough WF (1989) Chemical and isotopic systematics of oceanic basalts: implications for mantle composition and processes. In: SAUnders AD, Norry MJ (eds) Magmatism in the Ocean Basins, Geol Soc London Spec Pub 42: 313-345
Sylvester PJ (1998) Post-collisional strongly peraluminous granites. Lithos 45: 29-44

Windley BF, Kröner A, Guo J, Qu G, Li Y, Zhang C (2002) Neoproterozoic to Paleozoic geology of the Altai orogen, NW China: new zircon age data and tectonic evolution. J Geol 110: 719-737

Windley BF, Dmitriy A, Wenjiao X, Kröner A, Badarch G (2007) Tectonic models for accretion of the Central Asian Orogenic Belt. J Geol Soc, London 164: 31-47

Zen E, Hammastrom JM (1984) Magmatic epidote and its petrologic significance. Geology 12: 515-518 